\title{
Pathophysiology of obstructive sleep apnoea
}

\author{
P.C. Deegan, W.T. McNicholas
}

Pathophysiology of obstructive sleep apnoea. P.C. Deegan, W.T. McNicholas. (CERS Journals Ltd 1995.

ABSTRACT: The pathophysiology of obstructive sleep apnoea (OSA) is complex and incompletely understood. A narrowed upper airway is very common among OSA patients, and is usually in adults due to nonspecific factors such as fat deposition in the neck, or abnormal bony morphology of the upper airway.

Functional impairment of the upper airway dilating muscles is particularly important in the development of OSA, and patients have a reduction both in tonic and phasic contraction of these muscles during sleep when compared to normals. A variety of defective respiratory control mechanisms are found in OSA, including impaired chemical drive, defective inspiratory load responses, and abnormal upper airway protective reflexes. These defects may play an important role in the abnormal upper airway muscle responses found among patients with OSA. Local upper airway reflexes mediated by surface receptors sensitive to intrapharyngeal pressure changes appear to be important in this respect.

Arousal plays an important role in the termination of each apnoea, but may also contribute to the development of further apnoea, because of a reduction in respiratory drive related to the hypocapnia which results from postapnoeic hyperventilation. A cyclical pattern of repetitive obstructive apnoeas may result.

A better understanding of the integrated pathophysiology of OSA should help in the development of new therapeutic techniques.

Eur Respir J., 1995, 8, 1161-1178.
Dept of Respiratory Medicine and the Respiratory Sleep Laboratory, University College and St Vincent's Hospital, Dublin, Ireland.

Correspondence: W.T. McNicholas Dept of Respiratory Medicine

St. Vincent's Hospital

Elm Park

Dublin 4

Ireland

Keywords: Obstructive sleep apnoea sleep

upper airway physiology

Received: March 101995

Accepted for publication March 161995
The obstructive sleep apnoea/hypopnoea (OSA) syndrome is characterized by recurring episodes of upper airway obstruction during sleep, leading to markedly reduced (hypopnoea) or absent (apnoea) airflow at the nose/mouth. The condition is usually associated with loud snoring and hypoxaemia, and apnoeas are typically terminated by brief arousals, which result in marked sleep fragmentation and diminished amounts of slow wave sleep (SWS) and rapid-eye-movement (REM) sleep. Patients with OSA are usually unaware of this sleep disruption, but the changes in sleep architecture contribute significantly to the prominent symptom of chronic daytime sleepiness found in these patients. However, despite these findings during sleep, there may be no detectable respiratory abnormality whilst the patient is awake $[1,2]$.

The underlying pathophysiology of OSA is complex and not fully understood. However, it is generally accepted that stability and patency of the upper airway are dependent upon the action of oropharyngeal dilator and abductor muscles, which are normally activated in a rhythmical fashion during each inspiration [3]. The upper airway is subjected to collapse when the force produced by these muscles, for a given cross-sectional area (CSA) of the upper airway, is exceeded by the negative airway pressure generated by inspiratory activity of the diaphragm and intercostal muscles [3]. Upper airway obstruction can occur if the suction pressure is too high, or the counteracting forces of the upper airway dilating muscles are too weak, for any given suction pressure [4]. Contributing factors that promote upper airway obstruction include: anatomical narrowing of the upper airway; an excessive loss of upper airway muscle tone; and defective upper airway protective reflexes. A broad overview of the factors that contribute to the pathophysiology of OSA is given in table 1 .

\section{General factors}

Sex

Normal males have significantly higher pharyngeal and supraglottic resistances than normal females [5], which makes them more susceptible to pharyngeal collapse and OSA, and may contribute to the male predominance of the syndrome [1]. The mechanism underlying this higher upper airway resistance in males is unclear, but could be related to the greater incidence of obesity among males [5], to possible deleterious effects of male sex hormones $[6,7]$, or to a possible protective effect of female sex hormones [8]. 
Table 1. - Factors contributing to the pathophysiology of obstructive sleep apnoea

\begin{tabular}{|c|c|}
\hline General factors & $\begin{array}{l}\text { Anthropometric (male sex, age, obesity) } \\
\text { Drugs (ethanol, hypnotics) } \\
\text { Genetics }\end{array}$ \\
\hline $\begin{array}{l}\text { Reduced upper } \\
\text { airway calibre }\end{array}$ & $\begin{array}{l}\text { Specific anatomical lesions (enlarged ton- } \\
\text { sils, micrognathia) } \\
\text { Neck flexion } \\
\text { Nasal obstruction }\end{array}$ \\
\hline Mechanical factors & $\begin{array}{l}\text { Supine posture } \\
\text { Increased UA resistance } \\
\text { Increased UA compliance }\end{array}$ \\
\hline $\begin{array}{l}\text { Upper airway } \\
\text { muscle function }\end{array}$ & $\begin{array}{l}\text { Abnormal UA dilator muscle activity } \\
\text { Impaired relationship of UA muscle and } \\
\text { diaphragm contraction }\end{array}$ \\
\hline $\begin{array}{l}\text { Upper airway } \\
\text { reflexes }\end{array}$ & $\begin{array}{l}\text { Impaired response to negative pressure } \\
\text { Feedback from the lungs }\end{array}$ \\
\hline Central factors & $\begin{array}{l}\text { Reduced chemical drives } \\
\text { Increased periodicity of central drive } \\
\text { Inadequate response to breath loading }\end{array}$ \\
\hline Arousal & $\begin{array}{l}\text { Impaired arousal responses } \\
\text { Postapnoeic hyperventilation }\end{array}$ \\
\hline
\end{tabular}

UA: upper airway.

Age

Pharyngeal resistance increases with age in normal men, possibly related to greater body weight [5], and it is widely believed that the risk of developing OSA increases with age in men. However, this assumption is far from conclusive. One study has shown that, although there may be an increased incidence of sleep-disordered breathing among older ( $>50 \mathrm{yrs}$ ), otherwise healthy subjects compared to younger controls, the frequency of such sleep disordered events is not in the range of the OSA syndrome [9]. Another study demonstrated that $28 \%$ of randomly selected patients ( $>65 \mathrm{yrs}$ ) had apnoea frequencies of more than 5 episodes $\cdot \mathrm{h}^{-1}$, but many of these were asymptomatic, and it was suggested that an apnoea frequency in excess of 5 episodes $\cdot \mathrm{h}^{-1}$ may be a "normal" finding in this age group [10].

\section{Obesity}

Although weight in normal men correlates significantly with pharyngeal resistance [5] this relationship is lost when the influence of age is eliminated. Nevertheless, it has long been recognized that there is an association between obesity and sleep apnoea [11], and weight loss can be very beneficial in the management of OSA [1214].

One possible explanation for the relationship between obesity and OSA is that the upper airway is narrowed in obese patients as a result of increased fat deposition in the pharyngeal walls [15]. Studies using conventional computed tomography (CT) failed to identify any abnormal fat deposition in the immediate vicinity of the upper airway $[16,17]$. However, the development of magnetic resonance imaging (MRI), which can make use of specially "weighted" images to detect fat, has led to the demonstration of increased fat deposition surrounding the collapsible segment of the pharynx in patients with OSA $[18,19]$. The amount of fat detected also correlates with subject's apnoea/hypopnoea frequency (AHI) [19]. Another possible explanation for the relationship between obesity and OSA is the fact that obese subjects often have smaller lung volumes, particularly functional residual capacity (FRC), than nonobese subjects, which in turn can indirectly influence upper airway size and contribute to upper airway narrowing [20].

The upper airway may also be narrowed in obese patients with OSA as a result of external compression by superficially located fat masses [21, 22], and this could explain the finding that increased neck circumference correlates more closely than general obesity with the incidence and severity of OSA $[23,24]$. In an experimental model, lard-filled bags, simulating cervical fat accumulation, were applied to the anterior neck of supine anaesthetized rabbits and were found to increase upper airway resistance and decrease closing pressures [21].

\section{Genetics}

Several reports of families, in which multiple members were found to have OSA, suggest a possible genetic element [25-27]. Both clinical symptoms [28], and sleep laboratory evidence [29], of sleep-related breathing disorders are found to occur more frequently in the relatives of patients with OSA, than in the general population.

\section{Drugs}

Ethanol ingestion increases the frequency and duration of apnoeas because of the combined effects of reducing upper airway muscle tone and depressing the arousal response [30-32]. Ethanol also reduces genioglossus (GG) muscle activity during both quiet breathing and hypercapnia in healthy normal subjects [33]. Ethanol is believed to have a depressant effect on the reticular activating system (RAS), and appears to have more profound effects on the upper airway muscles than on the ventilatory pump muscles [33].

Both ethanol [34] and diazepam [35] significantly reduce hypoglossal nerve and GG electromyographic (EMG) activity in cats, at doses that produce little change in phrenic nerve and diaphragmatic (DIA) EMG activity. Ethanol also reduces GG responses to hypoxia and hypercapnia, whilst DIA responses are essentially unchanged [34]. Chloral hydrate [36] and anaesthetics [37] have a depressant effect on the RAS, with hypnotic doses of chloral hydrate preferentially depressing GG activity as compared with DIA activity [36]. This selective depression of upper airway muscle activity suggests that 
the respiratory activities of these muscles may be more dependent on the RAS than the bulbo-spinal phrenic system [34]. The importance of the relationship between upper airway muscles and the DIA is discussed below in "abnormalities of airway muscle function".

\section{Reduced upper airway calibre}

Factors that reduce upper airway calibre lead to increased upper airway resistance, with the generation of a more negative pharyngeal pressure during inspiration [38], and thereby predispose to upper airway occlusion during sleep. There are a number of recognized anatomical abnormalities that are associated with narrowing of the upper airway and predispose to OSA. Specific anatomical abnormalities are more frequently seen in children, particularly adenoidotonsillar enlargement [39-41]. Conditions associated with facial dysmorphism and/or mandibular abnormalities show a predisposition to OSA, and include choanal atresia [42], micrognathia [42, 43], and craniofacial dyostosis [42, 44]. Micrognathia is particularly associated with OSA, as a small and/or retropositioned mandible places the base of the tongue closer to the posterior pharyngeal wall and interferes with the efficiency of the GG muscle in keeping the tongue out of the narrowed pharynx [45]. Surgical correction of specific anatomical abnormalities, such as adenoidotonsillar enlargement, can result in partial or complete resolution of OSA [41, 46].

Infiltration of upper airway muscles and soft tissues can impair muscle function and reduce the upper airway lumen, as in myxoedema [47], acromegaly [48, 49], involvement by neoplastic processes [50], and mucopolysaccharidoses [51], all of which have been associated with a predisposition to OSA. Treatment of the underlying process can reverse upper airway obstruction $[47,50]$. Most adult patients with OSA, however, have no specific skeletal or soft-tissue lesion obstructing the upper airway, but often have a small congested oropharyngeal airway.

\section{Head position}

The position of the head and neck is an important factor in pharyngeal patency, with neck flexion capable of producing considerable increases in pharyngeal resistance during wakefulness and anaesthesia, particularly in obese subjects $[52,53]$. Varying head position between flexion and extension can cause significant variations in size of the retroglossal space and hyoid position on lateral cephalometry [23]. Neck flexion makes the upper airway more susceptible to collapse, whilst neck extension makes the upper airway more resistant to collapse [54], irrespective of changes in general body posture. Mouth opening can cause increased upper airway resistance, since this results in dorsal movement of the ventral attachments of upper airway dilator muscles, with resultant shortening in muscle length and reduction in efficiency [55].

\section{Nasal obstruction}

In normal individuals, the nose is the primary route of breathing during wakefulness, and more particularly during sleep [56], and the nose accounts for about half of the total respiratory resistance to airflow [57]. In the individual subject, nasal resistance can vary in relation to changes in nasal vascular congestion, posture, exercise, ambient air conditions, pharmacological agents, and disease [57]. A marked increase in nasal resistance is seen in patients with acute or chronic rhinitis when they become recumbent [58]. Unilateral nasal disease, such as polyps, can also cause increased nasal resistance in the lateral recumbent position if present in the uppermost nostril [59]. Nasal resistance is elevated in OSA patients [60-62], and the use of nasal decongestants can reduce supraglottic resistance in OSA [61]. Nasal occlusion in normal subjects leads to increased numbers of apnoeic episodes, sleep arousals, and awakenings [63-65], and increased numbers of apnoeas and hypopnoeas are also seen in patients with seasonal allergic rhinitis when symptomatic [66], or with a deviated nasal septum [67]. Nasal packing for epistaxis may induce OSA or exacerbate pre-existing OSA [68], whilst topical anaesthesia of the nose significantly increases the number of disordered breathing events in normal sleeping subjects $[69,70]$.

The capacity to sense both pressure and airflow in the upper airway may be important in the maintenance of respiratory rhythm during sleep [63], and nasal airflow has been reported to have a stimulant effect on breathing [71]. There is strong evidence, therefore, from a number of different perspectives, to support an important role for nasal dysfunction in the pathophysiology of OSA.

\section{Assessment of upper airway calibre}

Although upper airway occlusion is a dynamic process, much useful information relating to the anatomy of the upper airway can be obtained from a variety of imaging techniques, and to a lesser extent from the more dynamic assessment of flow-volume loops.

Diagnostic imaging. On lateral cephalometry, OSA patients have a variety of anatomical abnormalities, including an abnormally small airway below the base of the tongue, a long bulky soft palate, an inferiorly placed hyoid bone and retrognathia [72, 73]. Acoustic reflection [74] has demonstrated smaller mean CSA of the pharynx in awake OSA patients with apparently normal upper airway, when compared to a control group. However, in another study, no significant difference in pharyngeal area was seen between patients with OSA and a matched group of nonapnoeic snorers at FRC [75]. It should be noted that both of these techniques take measurements in the upright rather than supine body position.

CT measurements of CSA of the nasopharynx, oropharynx, and hypopharynx have been reported in awake supine patients with OSA [16, 17, 76-78]. All measurements 
were significantly reduced compared to control subjects in one study [16], which also failed to show any correlation between body mass index (BMI) and CT scan measurements. In a second report, only the retropalatal region was significantly narrower in OSA patients [17]; whilst in a third, no differences were found between patients and controls [77]. Differences in the lung volume at which pharyngeal CSA was measured could partially account for the apparent differences between these studies [20].

Pharyngeal size on CT scanning has been shown to correlate with pharyngeal resistance in patients with OSA, which in turn correlates significantly with AHI [77]. Patients with OSA undergoing uvulopalatopharyngoplasty (UPPP) were found to have minimal CSA at 10 and 20 $\mathrm{mm}$ below the hard palate preoperatively [76]. On follow-up, UPPP more than doubled upper airway CSA at these two levels, with the increase being greater among "responders" (defined as a greater than 50\% decrease in AHI post surgery) than "nonresponders". Patients with OSA also have significantly wider tongue and genioglossus muscles, on CT scanning, compared to nonapnoeic snorers and controls [78].

MRI studies have shown no correlation of pharyngeal volumes in apnoeic and nonapnoeic snorers, with AHI, weight or BMI [79]. However, on axial views, localized areas of upper airway narrowing were seen at different sites in different patients. This would suggest that the overall size of the pharynx is less important than the specific site of collapse.

Another important factor in the pathogenesis of OSA appears to be the shape of the upper airway [80]. Transverse sections on MRI show an elliptical shape, with the long axis oriented in the coronal plane in normal subjects, whereas in apnoeic and snoring patients the pharynx is circular or elliptical with the long axis oriented in the sagittal plane. This difference may be due to a reduction in lateral diameter, whilst increased forward movement of the tongue increases the anteroposterior diameter of the pharynx. This increased activity is lost during sleep leading to a decrease in pharyngeal CSA, which predisposes to upper airway collapse.

Flow-volume loops. Variable extrathoracic airway obstruction is present in $40 \%$ of subjects with sleep-disordered breathing, particularly in women [81]. The finding of a "saw-tooth pattern" on flow-volume loops has been reported to be a common and specific finding in OSA patients [82]. However, these criteria [81, 82] were present in only half of OSA subjects in a later study [72], although both correlated with reduced pharyngeal CSA on CT scanning [16].

The balance of evidence from the above reports indicates that the upper airway is significantly narrowed among patients with OSA compared to controls, but that the site of narrowing varies among OSA patients. This view is supported by a recent study using cine CT, that generated scans throughout the whole of the respiratory cycle and correlated them with airflow [83]. This study found that the upper airway was significantly smaller in OSA patients than in normal subjects, and that upper airway calibre varies throughout the respiratory cycle and is at its smallest at end-expiration, particularly in OSA patients [83].

\section{Mechanical factors}

Fibreoptic studies during obstructive apnoeas have shown abrupt collapse of the airway at the onset of inspiration, with opposition of the lateroposterior oropharyngeal walls in the pharynx and no evidence of glottic obstruction [84]. On lateral fluoroscopy [17], upper airway obstruction during inspiration is seen when the soft palate touches the posterior pharyngeal wall and the tongue. This obstruction usually ends when the tongue moves forward, the mandible lifts and the posterior pharyngeal wall moves posteriorly. This sequence of events enlarges the pharyngeal airway.

\section{Posture}

Most individuals assume the supine posture when they are asleep, despite the disadvantageous effects that this posture has on upper airway patency. Pharyngeal CSA is reduced from the upright to the supine position in normal subjects [85-87], and in both apnoeic and nonapnoeic snorers $[75,86]$. Supraglottic resistance is also greater in the supine than the sitting position, both for normal subjects and patients with OSA [61].

The effect of supine posture on upper airway patency does not result from decreased upper airway dilator muscle activity, since these muscles increase their EMG activity with the transition from the upright to the supine posture both in OSA and normal subjects [52, 85, 88]. There is also no evidence that the decrease in lung volume observed in the supine posture contributes to upper airway narrowing, since maintaining FRC constant in normal subjects from upright to supine does not prevent the fall in CSA [85]. Thus, the supine posture effect appears to be due to gravitational forces acting to narrow the upper airway [85]. However, patients with OSA often have a reduced FRC when upright, and the further fall in FRC when assuming the supine position may be associated with a significant fall in upper airway calibre [20].

\section{Upper airway resistance}

As outlined previously, patients with OSA have smaller upper airways than nonapnoeic subjects, and this is reflected in the finding of a higher awake inspiratory airflow resistance during wakefulness within the nasopharynx, in OSA patients compared to controls $[61,77]$. The onset of sleep leads to an increase in respiratory system resistance in healthy humans [38, 89-93], the increase being located almost entirely in the upper airway above the larynx [89], primarily at either the level of the palate or hypopharynx [94]. Although the nose can contribute significantly to upper airway resistance on assuming the supine posture, due to increased nasal mucosal congestion 
[61], there is little further increase in nasal resistance with the change from wakefulness to sleep [4]. The further increase in upper airway resistance with sleep onset is thought to result, instead, from a decline in upper airway dilator muscle tone during sleep.

Nonobese snorers have a greater increase in total airway resistance during non-REM (NREM) sleep than matched control subjects [95], and there is also a highly significant correlation between awake nasopharyngeal resistance and AHI during sleep [77, 96]. Inspiratory oropharyngeal resistance can reach high levels between apnoeas in patients with OSA [3, 60], and expiratory resistance also increases significantly as an apnoea approaches [97, 98].

\section{Upper airway compliance and collapsibility}

The segment of the upper airway extending from the nasal choanae to the epiglottis in humans lacks rigid or bony support, and may thus collapse in the absence of forces to maintain patency [99]. Marked variability in upper airway collapsibility is seen among normal men during sleep [91], and is thought likely to be related to both anatomical factors and alterations in ventilatory control during sleep. Pharyngeal compliance in snorers with OSA is increased compared to nonapnoeic snorers $[75,100]$, and patients with OSA have more collapsible upper airways during wakefulness than control subjects $[96,101]$. Increased pharyngeal compliance may, therefore, be more closely related to the development of OSA than pharyngeal CSA [100].

Patients with OSA have lower tonic muscle activity than snoring nonapnoeic controls, which appears to make their pharynx "floppier" [75]. This concept has been extended by viewing the upper airway as a Starling resistor, with a collapsible segment in the oropharynx, and flow through the upper airway governed by changes in pressure occurring upstream (nose) rather than downstream (hypopharynx) to the collapsible segment [102, 103]. Patients with OSA may, therefore, have an elevation of the critical collapsing pressure surrounding the upper airway, rather than changes in the resistive properties of the upper airway [102, 103].

Overall, the above data point to important differences in upper airway mechanics between normal subjects and patients with OSA, which are evident during wakefulness, but become more pronounced during sleep.

\section{Abnormalities of airway muscle function}

\section{Upper airway dilator muscle activity}

Patency of the collapsible segment of the upper airway is believed to be dependent on the function of pharyngeal dilator muscles [3, 104], which act to stiffen or distend the collapsible pharyngeal airway during inspiration, as suggested by the presence of EMG activity coordinated with respiration [105].
Activity of these upper airway muscles is modulated by chemical stimuli, vagal input, changes in upper airway pressure, and baroreceptor activity [106, 107]. Breathing through a narrowed upper airway generates a greater suction pressure and, thus, greater collapsing force, and pharyngeal dilator muscles must, therefore, contract more forcefully to prevent upper airway obstruction. Progressive hypercapnia, hypoxia, asphyxia and negative pressure application all produce an augmenting drive to upper airway dilator muscles [107-112]. Defects in such upper airway muscle responses, or inco-ordination of upper airway and diaphragm activity, have each been proposed as factors predisposing to OSA $[54,107,108$, $110,113,114]$. The complexity of the upper airway makes it unlikely that dysfunction of a single muscle group is responsible for OSA [104], and thus assessment of activity of any single muscle may not be a reliable index of upper airway obstruction [84].

The alae nasi (AN) dilate the anterior nares during inspiration, and the degree of preactivation of the AN EMG ahead of the DIA EMG may be used as an index of ventilatory drive to the upper airway [115]. During NREM sleep, AN preactivation increases from the beginning to the end of an apnoea, suggesting that ventilatory drive to the $\mathrm{AN}$ increases with apnoea duration [116]. This increase in preactivation, which is also seen in other upper airway muscles [115], could represent a compensatory attempt to open the airway before airway pressure is lowered by contraction of the DIA and ribcage (RC) muscles.

The genioglossus (GG) pulls the tongue forward and opposes pharyngeal collapse due to inspiratory negative pressure $[3,106,117,118]$, as shown by earlier peaking of GG EMG activity ahead of DIA EMG activity during inspiration [107]. Phasic inspiratory GG activity decreases with sleep in normal subjects [60, 105, 119], and almost ceases during REM sleep [117, 120]; whilst it increases significantly from wakefulness to NREM sleep, between apnoeas in OSA patients, and in older obese control subjects [121]. Thus, normal subjects have less activity than patients with OSA, yet do not have occlusive apnoeas, and such augmented activation of GG in OSA subjects may be viewed as a protective mechanism that occurs when patency of the pharyngeal airway is compromised. Any factor that interferes with this increase in GG activity, such as onset of phasic REM sleep or periodicity of central drive, can predispose to upper airway collapse. Indeed, GG EMG activity is reduced or abolished at apnoea onset, and increased at the termination of the obstruction [3, 121].

Muscles that cause forward movement of the hyoid bone (geniohyoid $(\mathrm{GH})$, sternohyoid (SH), thyrohyoid (TH)) are thought to enlarge and stabilize the pharyngeal airway [92, 122-126]. Both in normal subjects and those with OSA, adoption of a supine posture is associated with forward movement of the hyoid bone [86]. These muscles show phasic inspiratory activity, and greater mechanical activity with significant hypercapnia $[122,123]$. Both the GH and TH show augmented and prolonged activity after occlusion at end-expiration [122]. Phasic inspiratory activity of the GH is seen in 
normal awake subjects, with a sleep-related fall in tonic activity in all stages of sleep [92, 125], and there is a negative correlation with upper airway resistance [92]. Pharyngeal volume in anaesthetized cats displays an inverse relationship with hyoid muscle $(\mathrm{GH}, \mathrm{SH})$ length [124]. Factors that influence hyoid position, such as neck flexion or mandibular abnormalities, can adversely affect the function of these muscles leading to narrowing of the hypopharynx.

Reduced activity of the tensor palatini (TP) muscle, which retracts the palate from the posterior pharyngeal wall, thereby maintaining pharyngeal patency during nasal breathing, may also play an important role in the pathogenesis of OSA [127-130]. Tonic activity of the TP decreases during sleep and correlates with increased upper airway resistance during sleep[128, 131].

The overall conclusion that can be drawn from the above studies is that a variety of different muscle groups play an important role in the maintenance of upper airway patency. Muscles that control the tongue, palate and hyoid all appear to be involved in this process, but the literature so far gives different views on the relative importance of these muscle groups. Furthermore, it has been argued that airway compliance, independent of upper airway dilator muscle activity, may be the principal determinant of upper airway collapsibility [132]. The ability of the upper airway to resist collapse may, therefore, be dependent upon the mechanical arrangement of the mandible and hyoid bones, which allow for a specific pharyngeal size, and on the properties of the airway wall in the collapsible segment of the upper airway, rather than on upper airway dilator muscle activity [132].

\section{Relationship of upper airway and diaphragmatic EMG activity}

The EMG activities of upper airway muscles and DIA respond in a qualitatively similar manner to hypercapnia $[107,108,110,133]$, hypoxia [107-109, 133] and airway occlusion [107, 108]. This suggests that central control mechanisms of upper airway and respiratory pump muscles in humans are intimately related. Inspiratory activation of upper airway muscles occurs earlier than activation of the DIA $[104,115,134,135]$, which stabilizes the upper airway and counterbalances the collapsing force exerted on the upper airway by DIA and RC muscle activity [104]. Any reduction or delay in upper airway inspiratory muscle contraction, relative to DIA and RC muscle activity, predisposes to upper airway narrowing or collapse during sleep.

Activity of the hypoglossal nerve at lower levels of chemical drive (hypoxia and hypercapnia) is less than, and at higher levels of chemical drive greater than, phrenic nerve activity in anaesthetized dogs [108], although allowance must be made for the fact that anaesthesia selectively inhibits neural output to the upper airway [37]. Oxygen breathing in rabbits decreases GG more than DIA EMG, whilst hypercapnia and prolonged occlusions preferentially activate GG compared to DIA
[107]. Nonspecific respiratory stimuli (light, sound, touch) preferentially increase phasic inspiratory GG activity [107], similar to that seen with electroencephalographic (EEG) arousals at the termination of obstructive apnoeas [3]. Peripheral chemoreceptors appear to affect phasic inspiratory activity in the GG and DIA in qualitatively similar, but quantitatively different, ways. Nitrogen breathing and cyanide injection increase phasic inspiratory activity in the GG more than in the DIA [107], and these responses are abolished by carotid body denervation.

Some reports have suggested that respiratory motor drive to the pharyngeal musculature decreases during sleep, whereas output to the diaphragm is unchanged [15, 136], whilst others have suggested that a preferential decrease in upper airway muscle activity is not necessary for the development of occlusive apnoeas [114, 119, 137].

It has been hypothesized that patients with OSA have instability of ventilatory control similar to periodic breathing, and that occlusive sleep apnoeas occur when DIA and GG inspiratory EMG activity are both near the nadir of their cycle, which is lower than awake or sleep onset values [119]. After apnoea onset, these EMG activities tend to decrease further for the first 1-3 inspiratory efforts, and then progressively increase until resolution of the apnoea, at which time GG EMG appears to increase to a greater degree than DIA EMG and for 1-2 postapnoeic breaths (fig. 1). The period immediately following resolution of the apnoea is usually characterized by hyperventilation for several breaths, which normalizes arterial oxygen saturation $\left(\mathrm{Sa}_{2} \mathrm{O}_{2}\right)$. Both EMGs then decrease in activity, which predisposes to further occlusive apnoeas [119].

In addition, it has been speculated that the relative timing of inspiratory EMG activity of the upper airway to DIA and RC activity fluctuates during sleep in OSA [138]. As an obstructive apnoea approaches and upper airway inspiratory resistance progressively increases, inspiratory EMG activity of the upper airway muscles moves closer to and then falls behind RC EMG inspiratory activity [138]. Activity of the upper airway muscles remains behind the $\mathrm{RC}$ muscles during the apnoea, but again begins to precede activity of the RC muscles when the upper airway opens. This could represent periodicity of the respiratory controller [139], with reduced damping and increased gain. During tests of upper airway collapsibility in sleeping subjects with OSA, there was no evidence of increased drive to upper airway dilator muscles during progressive asphyxia, despite an apparent increase in drive to the DIA [140].

A clinical model of a disturbed timing relationship between upper airway and diaphragmatic contraction predisposing to OSA is seen in patients with diaphragmatic palsy treated with an electrophrenic pacemaker. About $50 \%$ of such patients develop OSA after insertion of this pacemaker [141, 142], since the pacemaker results in DIA contraction at times other than when upper airway muscles contract. The relationship between GG and DIA inspiratory activity is discussed further in "periodicity of central drive". 


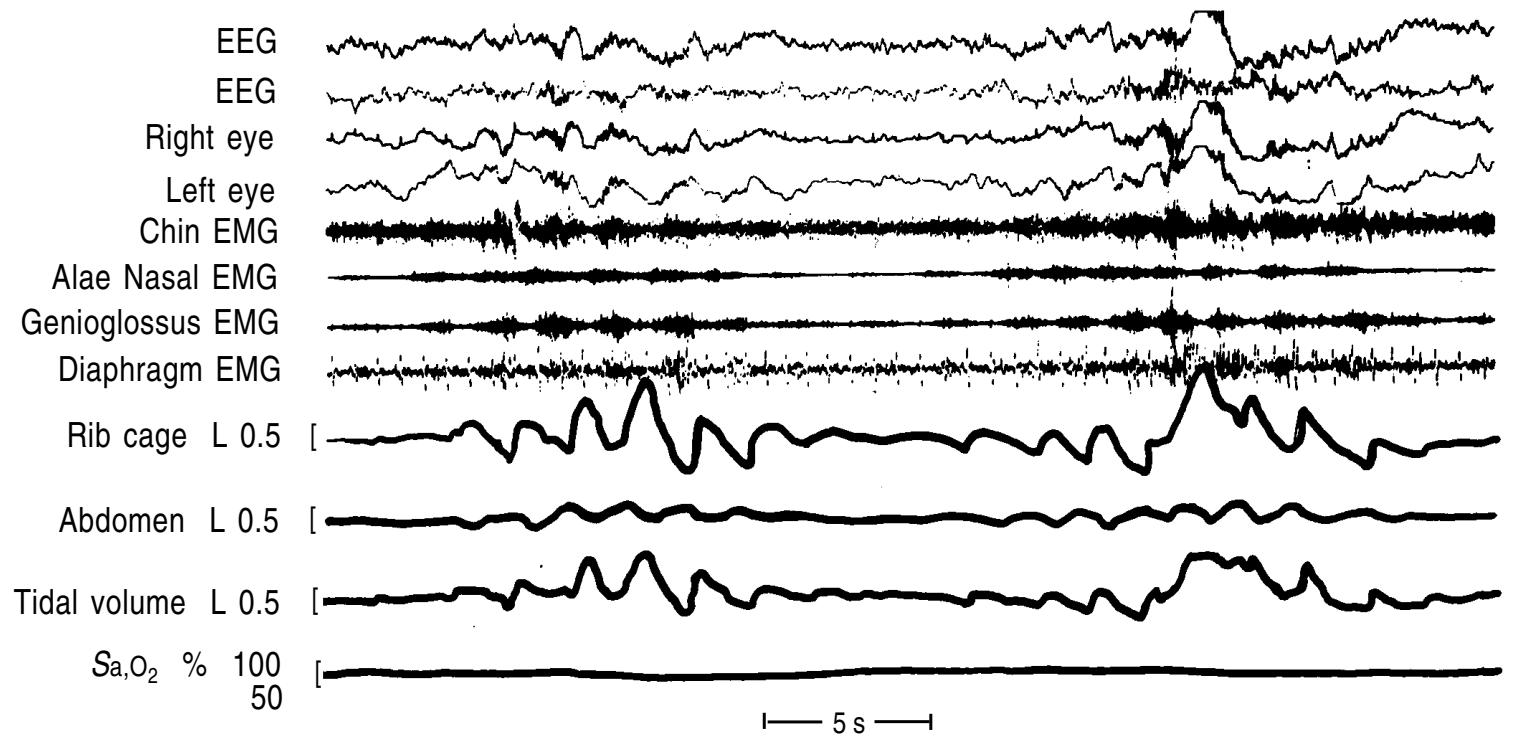

Fig. 1. - Cyclical changes in upper airway muscle and diaphragamatic EMG activity in association with repetitive obstructive apnoea from a patient with severe obstructive sleep apnoea syndrome. Note bursts of EMG activity at the termination of each apnoea, followed by marked falloff in EMG at the onset of each subsequent apnoea. EEG: electroencephalograph; EMG: electromyograph; $\mathrm{Sa}_{\mathrm{a}, \mathrm{O}_{2}}$, arterial oxygen saturation.

\section{Upper airway reflexes}

Several reports indicate a role for upper airway reflex mechanisms in the maintenance of patency $[111,112$, 143-149]. Evidence suggests that these reflex mechanisms are pressure sensitive [112, 144-146], and interference with them could lead to an imbalance between intrapharyngeal pressure and the contraction of upper airway dilating muscles, resulting in obstructive apnoeas [3]. The importance of such protective reflexes is supported by the finding of fatal pharyngeal airway closure in rabbits, in which upper airway reflexes are abolished by topical anaesthesia [150].

Topical oropharyngeal anaesthesia (TOPA) in normal human subjects results in increased frequency of obstructive apnoeas [69] and pharyngeal resistance [93] during sleep, independent of any direct effect of lignocaine on the upper airway muscles themselves [93]. A significant increase in obstructive events was seen after TOPA in a group of otherwise asymptomatic snorers [151], with several subjects developing AHIs that fall within the range of OSA as conventionally defined [1]. In contrast, TOPA did not produce any significant increase in AHI or apnoea duration among patients with OSA, which supports the possibility that upper airway reflexes are defective in OSA [152].

Defective upper airway reflexes may be a primary abnormality in OSA, contributing to the development of upper airway occlusion during sleep. However, such a defect could also be a secondary phenomenon, since the mechanical vibration of the upper airway, associated with loud snoring, might also blunt the afferent receptors for the reflex, which are presumed to lie in the oropharyngeal wall. Data from the above studies $[151,152]$ favour a primary abnormality in upper airway reflexes among OSA patients, since subjects with loud snoring would also be expected to have a mechanical vibration in the upper airway similar to that among patients with OSA.
Temperature sensitivity in the oropharynx in OSA patients is significantly impaired compared to age-matched nonsnoring control subjects [153], which further supports the notion that upper airway reflexes are impaired in patients with OSA.

\section{Responses to negative pressure}

Upper airway muscle EMG activity increases when negative pressure is applied to the isolated upper airway of tracheotomized rabbits [144, 145, 147], probably through reflexes involving mechanoreceptors located above the trachea, and via several afferent pathways. Small but consistent changes in respiratory frequency were also seen in many of the animals, suggesting some involvement of the respiratory centre in these changes [144].

Negative pressure applied to the upper airway in dogs causes a predominant increase in phasic activity of AN and posterior cricoarytenoid muscles and also in tonic activity of the GG, whilst preactivation of these muscles with respect to the DIA is increased [135]. A decrease in the rate of rise of DIA EMG with a prolongation of inspiratory time also occurs, and topical anaesthesia eliminates these responses [135].

In awake human subjects, the administration of sudden negative airway pressure to the upper airway leads to a pronounced and repeatable reflex increase in GG activity [111]. Contributions from both supraglottic and subglottic receptors appear to be involved, and topical anaesthesia blocks the response when the glottis is closed [112]. This response is reduced during NREM sleep [154]. Normal awake subjects exposed to continuous negative airway pressure (CNAP) whilst supine, are able to preserve tidal volume both by immediate and sustained increases in upper airway and DIA muscle activity [155]. However, during NREM sleep no immediate muscle or timing responses are seen with CNAP, and hypopnoeas 
and occlusive apnoeas result. Re-establishment of upper airway patency is dependent on arousal and increased muscle activity. These findings suggest that protective reflexes, which act to maintain upper airway patency in the presence of negative airway pressure during wakefulness, are compromised by sleep.

\section{Responses to positive pressure}

Continuous positive airway pressure, applied through the nares (nCPAP), is an effective therapy for OSA [156], and yet reduces upper airway dilator EMG activity [144, 157-159]. The efficacy of nCPAP, despite the association with reduced upper airway dilator muscle contraction, is fully consistent with the concept that suction pressures in the upper airway during inspiration cause the collapsible upper airway to occlude. This inspiratory suction pressure is abolished by nCPAP, and the reduction in upper airway dilator EMG activity during nCPAP administration is probably a consequence of the reduced need for upper airway dilating muscle contraction in the absence of any inspiratory negative suction pressure and to a possible splinting effect of the positive pressure.

End-expiratory positive airway pressure has been shown to reduce the frequency and duration of apnoeas and the degree of nocturnal oxygen desaturation, in patients with OSA [160]. However, as negative pressures are still developed in the upper airway during inspiration while on external positive airway pressure (EPAP), this improvement could not be attributed to simple splinting of the upper airway. This observation suggests an improvement in other factors that may be contributing to the development of upper airway occlusion during sleep, such as decreased FRC and/or hypoxaemia [161].

\section{Feedback from the lungs}

Pharyngeal CSA is abnormally small in obese patients with OSA, and varies considerably with changes in lung volume [20, 162]. The mean CSA of the upper airway in snorers with OSA appears to be significantly less than in nonapnoeic snorers at residual volume, but not at FRC [100]. Upper airway resistance tends to decrease with increasing lung inflation and with increasing breathing rates at low volumes [53]. The above observations support the notion that vagally-mediated reflexes related to lung volume can have an important influence on upper airway calibre [134].

\section{Central factors}

Abnormalities of respiratory control have been implicated in the pathogenesis of OSA [119, 163], and could conceivably occur at several levels ranging from the respiratory centre to peripheral upper airway reflex mechanisms.

\section{Chemical drive}

The sleeping state is associated with a reduction in minute ventilation [164-166], and in the ventilatory responses to hypoxia and hypercapnia [167-170], compared with wakefulness. The mechanism underlying these reductions is not thought to be due exclusively to decreased central respiratory drive [171], and may relate, at least in part, to mechanical changes, such as reduced upper airway patency during sleep [38, 89, 95]. Support for this possibility comes from the observation that mouth occlusion pressure $\left(P_{0.1}\right)$, which is a better index of respiratory drive than the ventilatory response [172], increases from wakefulness to NREM and REM sleep in men, with little change in women; and the $P 0.1$ response to hypercapnia is generally maintained during NREM sleep in comparison to wakefulness [171].

Upper airway resistance in OSA appears to be influenced by the intensity of the central respiratory drive, as determined by relating measurements of $P 0.1$ to mean inspiratory flow [173]. At specific levels of respiratory drive posthyperventilation, a similar decrease in central respiratory drive leads to a greater increase in pharyngeal resistance among OSA patients than among normal subjects, which is not explained by differences in weight and age [173].

Eucapnic OSA patients have been reported as having a normal [1, 174], or reduced [175], awake hypercapnic ventilatory response, whilst obese OSA patients with daytime hypercapnia have reduced awake ventilatory and $P 0.1$ responses to hypercapnia [176]. Most patients with OSA are eucapnic and demonstrate augmented ventilation after apnoeas, with tidal volume of breaths as much as double that of breaths preceding apnoeas; whilst hypercapnic patients do not display this "big breath phenomenon" [176]. In another study, hypercapnic ventilatory responses in obese patients with OSA, and in patients with obesity-hypoventilation, were significantly lower than in normal nonobese subjects subjected to abdominal mass loading, and in obese subjects without OSA [177]. However, analysis of $P 0.1$ and mean DIA EMG responses in this study shows that obesity may be associated with impaired respiratory neuromuscular coupling, which in turn may impair transfer of ventilatory drive to muscle contraction [177]. Thus, ventilation may be an inadequate parameter to assess central respiratory drive in these patients, and $P 0.1$ responses are likely to give a better indication of central respiratory drive in obese subjects.

It is uncertain whether the observed reduction in chemical drives is a primary defect [27], or secondary to sleep apnoea, as suggested by some improvement in the ventilatory response to $\mathrm{CO}_{2}$ in hypercapnic OSA patients after long-term nCPAP therapy [178].

\section{Periodicity of central drive}

Variability in inspiratory muscle timing among patients with OSA could result from periodicity of the central respiratory controller $[138,139]$. During the hypopnoeic portion of the periodic breathing cycle, when ventilatory drive is low, both the relative amplitude and the relative timing of the inspiratory activity of the upper airway and chest wall muscles favour upper airway occlusion, since 
there is a greater fall in amplitude of upper airway muscle EMG than diaphragmatic EMG, and the normal preactivation of upper airway EMG is not apparent. On the other hand, an obstructive apnoea is terminated when the drive to the upper airway muscles is stimulated to a degree such that the magnitude of increase in upper airway dilator muscle activity exceeds that of the respiratory muscles, allowing opening of the upper airway and resumption of airflow.

In addition, total pulmonary resistance can double in the period from immediately after an upper airway occlusion to immediately before the next one [60]. As ventilation falls around the onset of apnoea, oesophageal pressure swings associated with respiration remain unchanged. However, it would be expected that increased pressure swings would be seen, as the upper airway starts to collapse and become reduced in calibre. The lack of such an increase in amplitude of the pressure swings further suggests a decrease in central respiratory drive at the onset of apnoea, with failure of appropriate arousal and respiratory responses during the first several occluded respiratory efforts.

An arterial carbon dioxide tension $\left(P \mathrm{a}, \mathrm{CO}_{2}\right)$ threshold well above the eupnoeic level is observed for GG muscle stimulation during all stages of sleep and wakefulness, whilst the DIA shows increased activity at even minor degrees of hypercapnia [120]. This imbalance of activity, which favours upper airway collapse, seems to be greatest during phasic REM sleep. In the setting of respiratory instability, such as in periodic breathing, $P \mathrm{a}, \mathrm{CO}_{2}$ may oscillate around the GG EMG threshold, to set up a cycle of recurrent airway occlusion and recovery. In sleeping OSA patients, the induction of hypercapnia during sleep preferentially stimulates upper airway inspiratory muscle tonic activity relative to chest wall inspiratory muscle activity, and this reduces periodic breathing and apnoea duration [179].

The maintenance of rhythmic breathing in hypoxia is dependent upon the neurophysiological state of the higher central nervous system (CNS) [164]. Hypoxia causes periodic breathing during all stages of NREM sleep, and apnoea is produced when end-tidal $\mathrm{CO}_{2}$ is reduced by $1-3 \mathrm{mmHg}$ below spontaneously breathing awake levels, with apnoea length positively correlated with the magnitude of hypocapnia. These findings point to a highly sensitive $\mathrm{CO}_{2}$-dependent apnoeic threshold during NREM sleep. It has been proposed that the combination of augmented peripheral chemoreceptor "gain" in hypoxia, together with the hypocapnia-induced apnoeic threshold in NREM sleep, provides the basis for the initial occurrence of apnoea, in addition to the hyperventilation that immediately follows the termination of apnoea. This hyperventilation subsequently leads to hypocapnia, which predisposes to further apnoea and contributes to the self-sustaining nature of periodicbreathing [164].

\section{Response to breath loading}

Resistive load detection thresholds during wakefulness are significantly greater among patients with OSA than control subjects, and the degree of load detection impairment correlates with the severity of OSA [163]. A significant negative correlation between the awake ventilatory response to hypercapnia and load detection threshold was seen both in patients and control subjects (fig. 2). Furthermore, since awake inspiratory load compensation in patients with OSA is normalized after a period of nCPAP treatment, such impairment may be a reversible consequence, rather than a cause, of OSA [180].

If conscious factors are important in ventilatory load compensation, then the loss of these influences with sleep onset may result in an inadequate response. Normal subjects can fully compensate for external resistive loads [91, 181-183] and external elastic loads [184] during wakefulness by immediate adjustments in ventilatory timing, and minute ventilation is maintained at preloading levels. During NREM sleep, however, there is an immediate fall in minute ventilation following load application, largely due to a reduction in tidal volume. This fall becomes less marked with time due to a rise in $P \mathrm{a}_{\mathrm{C}} \mathrm{CO}_{2}$ that results in augmented ventilatory effort [183, 184].

However, it has been speculated that this lack of augmentation of respiratory drive, when a partial airway occlusion occurs during sleep, may permit forward motion of the tongue rather than the tongue being sucked backwards into the pharynx by the higher suction pressures generated with greater respiratory effort. This balance of forces could prevent the progression from partial to complete upper airway obstruction [182].

Another factor in ventilatory load compensation is thought to be a reflex originating in respiratory muscles that are fatiguing and/or developing high intrathoracic pressure. Neural information from these respiratory muscles is fed back to the respiratory centre, which in turn may modulate output so that the respiratory muscles are unloaded. A fatiguing respiratory pattern may

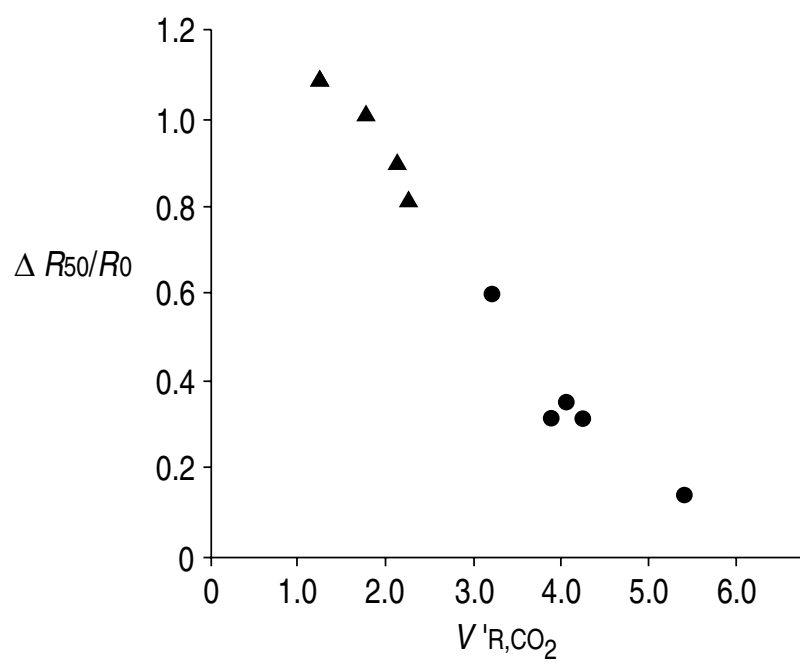

Fig. 2. - Relationship between threshold for detection of inspiratory flow-resistive loads, normalized for background resistance $(\Delta \mathrm{R} 50 / \mathrm{R} 0)$, and the response of minute volume of ventilation to progressive hypercapnia in $\mathrm{L} \cdot \mathrm{min}^{-1} \cdot \mathrm{mmHg}\left(\mathrm{V}^{\prime} \mathrm{R}, \mathrm{CO}_{2}\right)$. $\boldsymbol{\Delta}$ : patients with obstructive sleep apnoea; O: normal subjects. (Modified [163]). 
occur during an obstructive apnoea [185], with each occluded inspiratory effort associated with increasing tension time index of the diaphragm. When this index reaches or exceeds the fatigue threshold, arousal may result, followed by opening of the upper airway [186, 187]. Thus, the airways may be triggered to open by a protective reflex originating in the larynx, or the inspiratory muscles, upon reaching a certain degree of contraction.

If perception of upper airway occlusion during sleep, by mechanoreceptors or inspiratory muscles, is involved in eliciting the arousal response that terminates each apnoeic event, it could be argued that elevation of the threshold for load detection might contribute to prolongation of sleep apnoeas and result in a more severe degree of asphyxia. However, the lack of prolongation of apnoea with topical anaesthesia among normal subjects [69], loud snorers [151], and patients with OSA [152] could argue against the possibility of increased duration of apnoeas due to reduced upper airway pressure detection, although another preliminary report has indicated prolongation of apnoea with such anaesthesia in OSA patients [188].

\section{Voluntary breathholding}

There are a number of chemical and mechanical factors that affect the duration of voluntary breathholding, a manoeuvre that simulates some features of an obstructive apnoea [189]. These include hypoxaemia and hypercapnia, both of which shorten maximum breathhold time. Hyperventilation lengthens the breathholding time by lowering the initial $\mathrm{Pa}_{\mathrm{a}} \mathrm{CO}_{2}$. In addition, if a few breaths of a gas that does not alter $\mathrm{Pa}_{\mathrm{a}} \mathrm{CO}_{2}$ are taken at the breaking point of a breathhold, the subject will be able to resume the breathhold. Thus, the unpleasant sensation experienced as the breaking point is reached is not due solely to hypercapnia [189].

In another study, involuntary respiratory muscle contractions (recorded as waves of negative pressure) were found in most individuals during breathholding, and increased in amplitude and frequency throughout the breathhold time [190]. The slopes of the pressure waves $(\mathrm{d} P / \mathrm{dt})$ during breathholding were found to be greater than those in the same subjects at the same $\mathrm{CO}_{2}$ level during rebreathing. This suggested that the response is due, in part, to a number of other, possible nonchemical, stimuli [190].

\section{Effects of oxygen supplementation}

The role of $\mathrm{O}_{2}$ desaturation in the pathophysiology of OSA may be assessed indirectly by observing the effects of $\mathrm{O}_{2}$ supplementation. Nocturnal oxygen improves $\mathrm{S}_{\mathrm{a}, \mathrm{O}_{2}}$ in patients who have sleep-disordered breathing [191-195], but there is no objective evidence of any improvement in daytime sleepiness [192, 194, 195], although some patients report greater alertness. Administration of $100 \% \mathrm{O}_{2}$ acutely [191], and $\mathrm{O}_{2}$ at
$4 \mathrm{~L} \cdot \mathrm{min}^{-1}$ throughout the night [193], eliminates [191] or reduces [193] bradycardia associated with sleep apnoea. Added oxygen increases the length of apnoeas and hypopnoeas [191-193], as well as increasing $\mathrm{Pa}_{\mathrm{a}, \mathrm{CO}_{2}}$, and this results in a lower $\mathrm{pH}$ at the end of apnoeic events [192, 193]. Supplemental oxygen can reduce apnoea frequency, possibly by reducing postapnoeic hyperventilation and stabilizing ventilatory drive [192].

\section{Arousal}

Arousal from sleep in normal males is accompanied by an immediate fall in upper airway resistance to awake values [91], whilst termination of an obstructive apnoea is believed to depend heavily on arousal [3, 140, 196]. Thus, arousal mechanisms may have an important role to play in the pathophysiology of OSA [196]. In normal individuals, when relief of upper airway occlusion is accompanied by arousal, there is a fall in pharyngeal resistance and a drop in end-tidal carbon dioxide tension $\left(P \mathrm{ET}, \mathrm{CO}_{2}\right)$ due to hyperventilation [197]. However, when no arousal occurs, hyperventilation is obtunded and both $P \mathrm{ET}, \mathrm{CO}_{2}$ and pharyngeal resistance rise (fig. 3). In patients with OSA, evidence of arousal usually precedes or coincides with the preferential increase in upper airway tone that restores airway patency and terminates the obstructive apnoea [3]. However, the mechanisms by which airway occlusion, hypoxia, and hypercapnia lead to arousal from sleep remain unclear and it is unlikely that any single factor is responsible for arousal.

It has been hypothesized that airway occlusion activates pressure-sensitive upper airway mechanoreceptors and that these play an important role in early arousal from upper airway occlusion, as nasal occlusion leads to shorter times to arousal compared to tracheal occlusions in sleeping dogs [198]. The finding that topical upper airway anaesthesia significantly prolongs the time to EEG arousal in response to induced airway occlusion in normal human subjects [199] also supports an important role for upper airway receptors in facilitating the arousal response. Responses to irritant receptor stimulation are blunted during sleep compared to wakefulness, with the degree of laryngeal and tracheobronchial stimulation required to produce arousal during REM sleep higher than in SWS [200, 201]. Cough and smooth muscle contraction in response to bronchopulmonary irritant stimuli appear to be dependent on arousal, and arousal responses to such stimuli are depressed in REM sleep [200]. Pulmonary stretch receptors stimulated by lung inflation do not cause arousal, but readily produce apnoea and tracheal smooth muscle relaxation during SWS [200].

Total airway occlusion during NREM sleep in normal subjects is characterized by a breath-by-breath progressive increase in suction pressure prior to arousal, that is achieved by an increase in the rate of inspiratory pressure generation [113]. In contrast, during REM sleep, arousal occurs after a shorter duration of airway occlusion than NREM, and the period of occlusion is associated with a rapid shallow breathing pattern. These 
EEG $50 \mu \mathrm{V}$

EMG
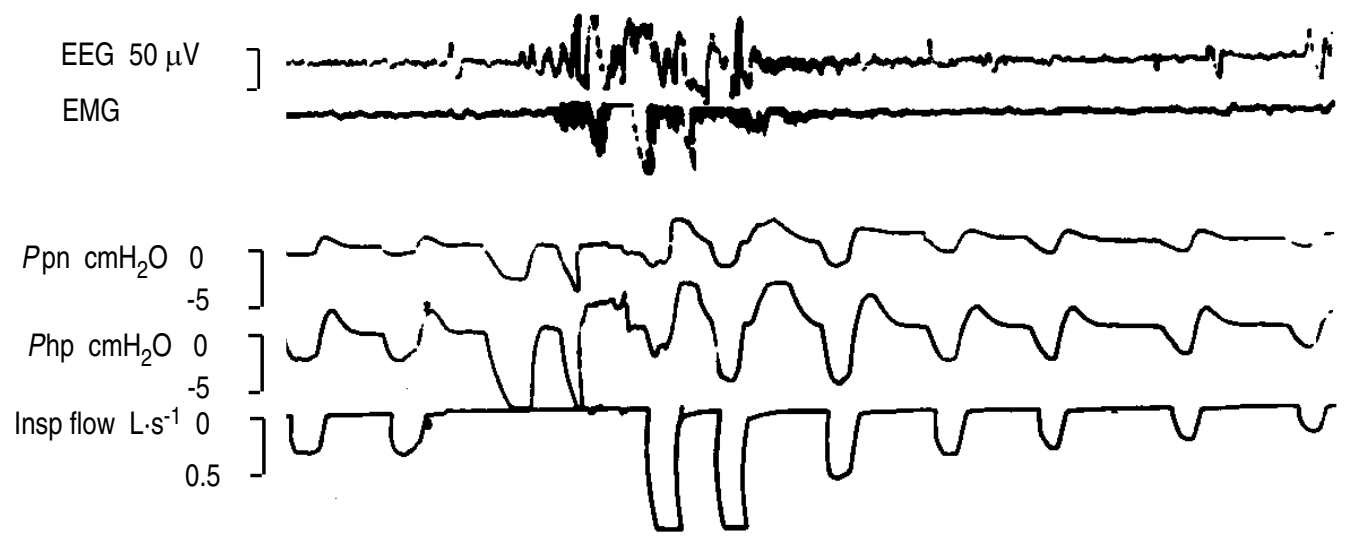

$\mathrm{PET}, \mathrm{CO}_{2} \quad \mathrm{mmHg} \quad \mathrm{O}$

50
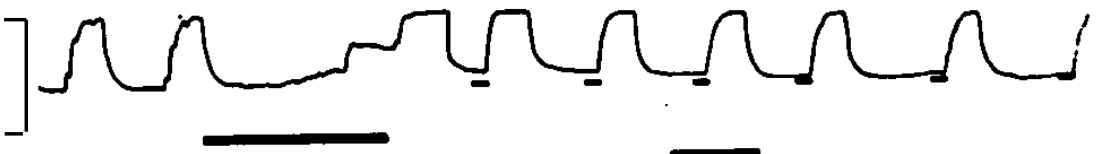

EEG $50 \mu \mathrm{V}$

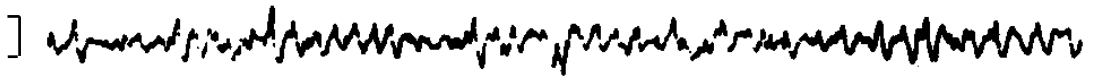

EMG
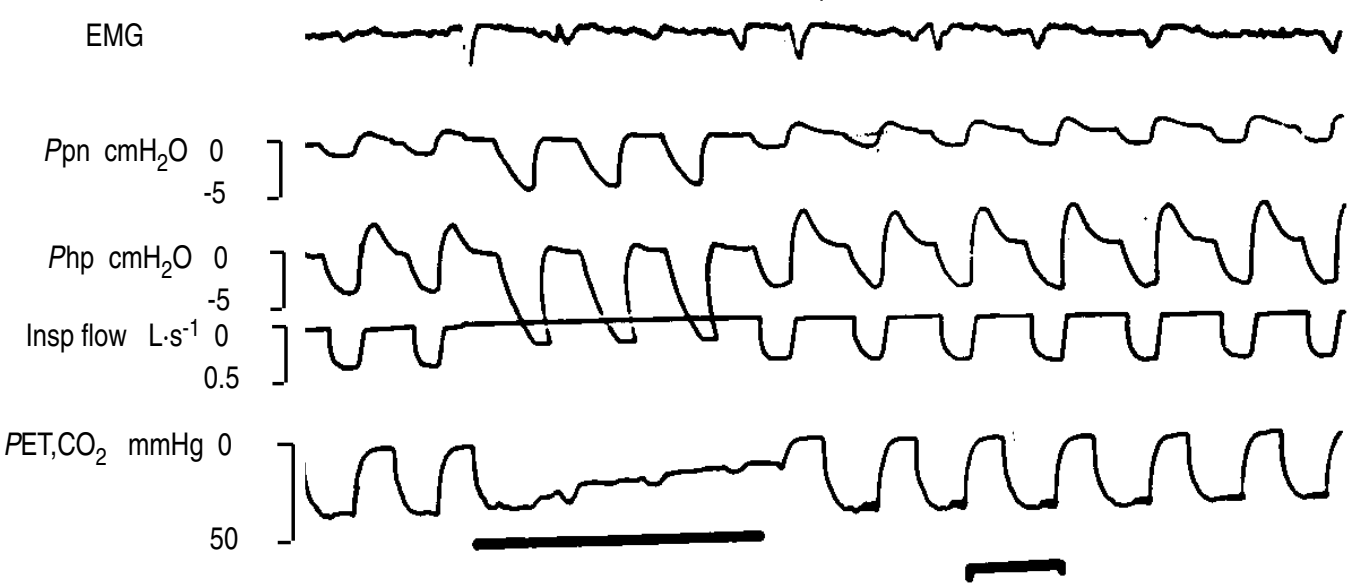

Fig. 3. - Relationship between arousal and postapnoeic hyperventilation in a normal subject following experimentally induced airway occlusion. Upper panel represents an occlusion associated with arousal, and lower panel represents an occlusion associated with no evidence of arousal. Note the increased tidal airflow and fall in end-tidal $\mathrm{CO}_{2}$ in the occlusion associated with arousal, in comparison to the occlusion where no arousal occurred. EEG: electroencephalograph; EMG, electromyograph; $P$ pn: postnasal pressure; $P$ hp hypoharyngeal pressure; Insp flow: inspiratory flow; $P$ ET, $\mathrm{CO}_{2}$ : end-tidal carbon dioxide tension.

findings are surprising, and contrast with the clinical situation in OSA, where apnoeas during REM sleep tend to be longer than during NREM sleep. The increasing ventilatory effort associated with the obstructive apnoea may also be an important factor that contributes to arousal, mediated by mechanoreceptor feedback from the respiratory system, probably from respiratory muscles $[187$, 202].

Hypoxaemia stimulates specific receptors in the carotid body [203, 204]. Carotid body denervation in sleeping dogs leads to failure of arousal during progressive hypoxia [204], and to large increases in oxygen desaturation and time to arousal following airway occlusion [203]. However, hypoxia has been shown to be poorly related to arousal in normal humans [168], and in patients with chronic obstructive pulmonary disease [205]. In addition, increased upper airway resistance during sleep, below the threshold for frank apnoeas or hypopnoeas, can still produce frequent brief arousals and significant daytime sleepiness in the absence of $\mathrm{O}_{2}$ desaturation [206].
Hypercapnia, which activates receptors in the upper airway and medulla, appears to be a much more potent stimulus to arousal than hypoxia [167-170, 207]. In normal subjects, exposed to hypoxia, hypercapnia and inspiratory resistive loading during sleep, arousal occurred at different levels of blood chemistry $\left(\mathrm{S}_{\mathrm{a}, \mathrm{O}_{2}}\right.$ and $\left.\mathrm{CO}_{2}\right)$ but the ventilatory effort for each subject was similar at the point of arousal regardless of the stimulus [202]. It has, therefore, been concluded that increasing ventilatory effort may be the stimulus to arousal from sleep independent of the source of this rising drive to breathe [202].

At present, any definition of arousal from sleep will be arbitrary, since there is no universal agreement as to what exactly constitutes an arousal. This difficulty in defining arousal relates largely to the limitations of the standard ReChTSCHAFFEN and KALES [208] criteria, which are the current gold standard for staging sleep. Newer criteria, based on spectral analysis of the EEG during sleep [209], will almost certainly improve the ability to classify arousal, and the advent of computerized software 
for EEG analysis will facilitate this development. A recent preliminary report, based on spectral analysis of the EEG, has demonstrated that the arousal associated with the termination of obstructive apnoea is not a sudden event that occurs at the termination of apnoea, and that there is evidence of partial arousal developing from much earlier on during the course of the apnoea [210].

The arousal response does not usually lead to complete awakening, but rather may cause lightening of sleep, with a shift from a deeper sleep stage to a lighter stage, or alternatively there may be no formal change in sleep stage by conventional definition, but short bursts of alpha waves may occur at the termination of apnoea. These sleep stage/state changes lead to sleep fragmentation, which in turn can worsen the underlying OSA [32].

However, all apnoeic events do not necessarily end with an EEG arousal, whilst EEG changes are not essential for an arousal response to have occurred. Nevertheless, the above data support the view that arousal represents a protective mechanism to restore ventilation, and normalize blood gases, whenever the upper airway is occluded. Thus, any factor that interferes with the arousal mechanism could lead to more profound and prolonged apnoeas. However, arousals themselves could potentially predispose to further apnoeas by virtue of the hyperventilation that occurs with relief of upper airway obstruction [197]. As outlined previously, the resultant fall in $P_{\mathrm{ET}, \mathrm{CO}_{2}}$ and increase in $\mathrm{Sa}_{\mathrm{a}} \mathrm{O}_{2}$ will predispose to further occlusion of a compromised upper airway.

\section{Integrated pathophysiology of obstructive sleep apnoea}

The foregoing discussion indicates the complexity of the pathophysiology of OSA. Various factors, ranging from upper airway anatomy to central respiratory control mechanisms, interact to produce the clinical syndrome of OSA. Different factors will predominate in individual patients, but it is likely that all patients with clinically significant OSA have a multifactorial aetiology, rather than any single causative factor. Specific anatomical narrowing of the upper airway occurs in only a subgroup of patients with OSA [1], and thus other factors are likely to play a role in the development of the clinical OSA syndrome. However, these factors, such as defects in ventilatory control and protective upper airway reflexes, are less easily defined and further research is needed to elucidate their precise role in maintaining upper airway patency during sleep.

The role of central factors in the development of OSA is underlined by reports in the early literature related to OSA that successful relief of OSA by tracheostomy is frequently followed by evidence of central sleep apnoea [211]. Furthermore, the division between

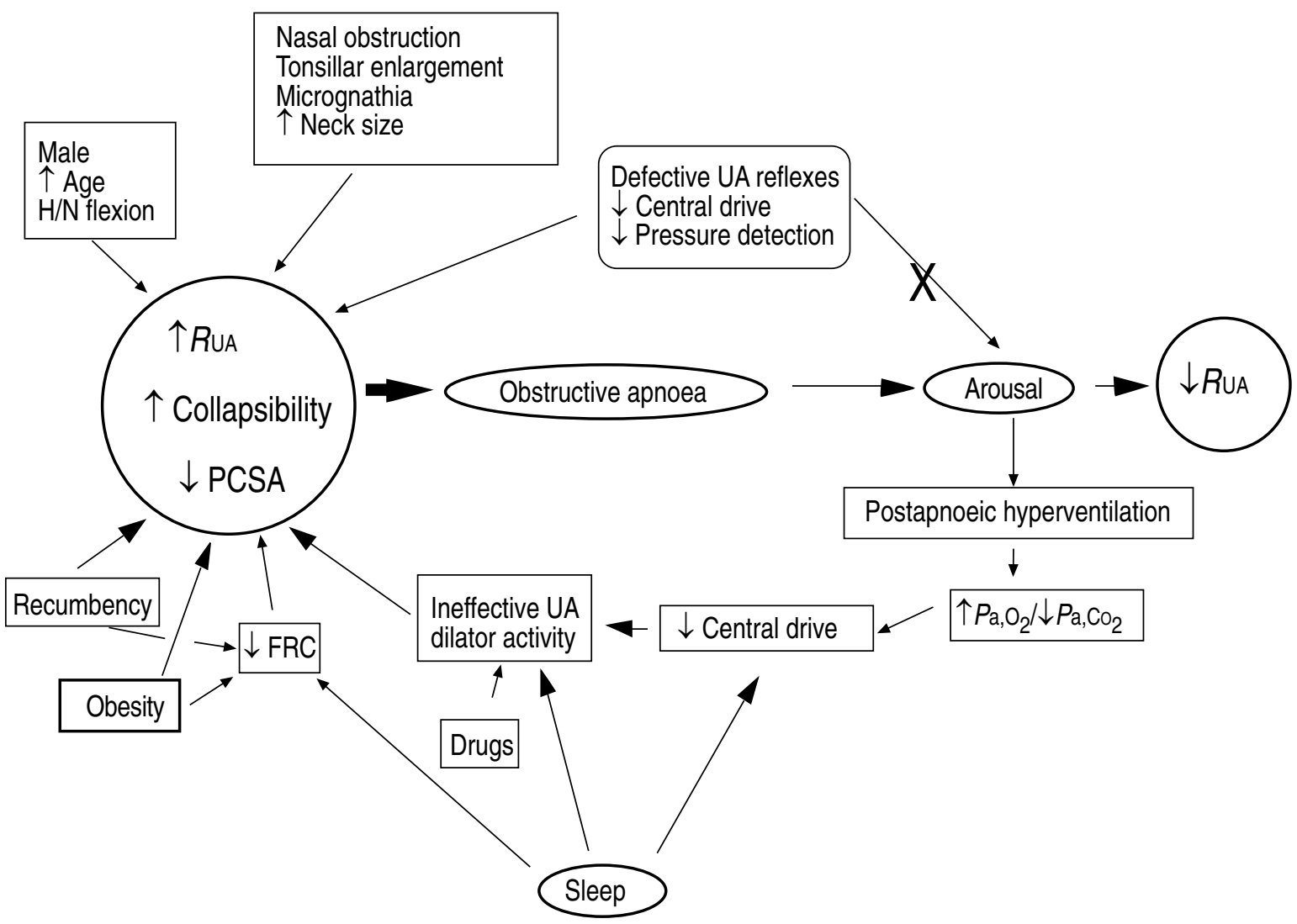

Fig. 4. - Schematic illustration of the integrated pathophysiology of obstructive sleep apnoea. UA: upper airway; H/N: head and neck; $R$ UA upper airway resistance; PCSA: pharyngeal cross-sectional area; FRC: functional residual capacity; $P \mathrm{a}_{2} \mathrm{O}_{2}:$ arterial oxygen tension; $P$ a, $\mathrm{CO}_{2}$ : arterial carbon dioxide tension. -X-: impairment of arousal mechanisms. 
central and obstructive sleep apnoea is not as clear-cut as it might appear, since many patients with central sleep apnoea present with clinical features more suggestive of OSA [212], and it is possible that in some patients, upper airway occlusion reflexly triggers a central, rather than an obstructive apnoea. Support for this notion comes from the finding that some patients with central sleep apnoea can be successfully treated with nCPAP [212].

A schematic illustration of the integrated pathophysio$\operatorname{logy}$ of OSA is given in figure 4. This illustration underlines the complexity of the overall pathophysiology, but emphasizes the central features, with factors that compromise upper airway patency and promote obstruction on the one hand, and other factors, principally arousal, which act to restore upper airway patency.

The current management of moderate to severe OSA is largely dependent on nCPAP, in the absence of surgically correctable anatomical lesions obstructing the upper airway. Whilst nCPAP is highly effective in controlling OSA, the device is cumbersome, and compliance data demonstrate only moderately satisfactory compliance with this form of therapy [213-215]. A better understanding of the interacting factors that lead to the development of clinically significant OSA will, hopefully, lead to the development of simpler modalities of therapy.

\section{References}

1. Guilleminault C, Tilkian A, Dement WC. The sleep apnea syndromes. Annu Rev Med 1976; 27: 465-484.

2. Stradling JR, Phillipson EA. Breathing disorders during sleep. $Q J$ Med 1986; 58: 3-18.

3. Remmers JE, DeGroot WJ, Sauerland EK, Anch AM. Pathogenesis of upper airway occlusion during sleep. $J$ Appl Physiol: Respirat Environ Exercise Physiol 1978; 44: 931-938.

4. Hudgel DW, Hendricks C, Hamilton HB. Characteristics of the upper airway pressure-flow relationship during sleep. J Appl Physiol 1988; 64: 1930-1935.

5. White DP, Lombard RM, Cadieux RJ, Zwillich CW. Pharyngeal resistance in normal humans: influence of gender, age and obesity. J Appl Physiol 1985; 58: 365-371.

6. Johnson MW, Anch AM, Remmers JE. Induction of the obstructive sleep apnea syndrome in a woman by exogenous androgen administration. Am Rev Respir Dis 1984; 129: 1023-1025.

7. Cistulli PA, Grunstein R, Sullivan CE. Effect of testosterone administration on upper airway collapsibility during sleep. Am J Respir Crit Care Med 1994; 149: 530-532.

8. Block AJ, Wynne JW, Boyson PG. Sleep-disordered breathing and nocturnal oxygen desaturation in post menopausal women. Am J Med 1980; 69: 75-79.

9. Bixler EO, Kales A, Cadieux RJ, Vela-Bueno A, Jacoby JA, Soldatos CR. Sleep apneic activity in older healthy subjects. J Appl Physiol 1985; 58: 1597-1601.

10. Ancoli-Israel S, Kripke DF, Mason W, Kaplan OJ. Sleep apnoea and periodic movements in an aging sample. $J$ Gerontol 1985; 40: 419-425.

11. Walsh RE, Michaelson ED, Harkleroad LE, Zighelboim A, Sackner MA. Upper airway obstruction in obese patients with sleep disturbance and somnolence. Ann Intern Med 1972; 76: 185-192.

12. Harman EM, Wynn JW, Block AJ. The effect of weight loss on sleep-disordered breathing and oxygen desaturation in morbidly obese men. Chest 1982; 82: 291-294.

13. Browman CP, Sampson MG, Yolles SF, et al. Obstructive sleep apnea and body weight. Chest 1984; 85: 435-436.

14. Suratt PM, McTier RF, Findley LJ, Pohl SL, Wilhoit SC. Changes in breathing and the pharynx after weight loss in obstructive sleep apnea. Chest 1987; 92: 631-637.

15. Remmers JE, Anch AM, DeGroot WJ. Respiratory disturbances during sleep. Clin Chest Med 1980; 1: 57-71.

16. Haponik EF, Smith PL, Bohlman ME, Allen RP, Goldman SM, Bleecker ER. Computerized tomography in obstructive sleep apnea: correlation of airway size with physiology during sleep and wakefulness. Am Rev Respir Dis 1983; 127; 221-226.

17. Suratt PM, Dee P, Atkinson RL, Armstrong P, Wilhoit SC. Fluoroscopic and computed tomographic features of the pharyngeal airway in obstructive sleep apnea. $\mathrm{Am}$ Rev Respir Dis 1983; 127: 487-492.

18. Horner RL, Mohiaddin RH, Lowell DG, et al. Sites and sizes of fat deposits around the pharynx in obese patients with obstructive sleep apnoea and weight-matched controls. Eur Respir J 1989; 2: 613-622.

19. Shelton KE, Woodson H, Gay S, Suratt PM. Pharyngeal fat in obstuctive sleep apnea. Am Rev Respir Dis 1993; 148: 462-466.

20. Hoffstein V, Zamel N, Phillipson EA. Lung volume dependence of pharyngeal cross-sectional area in patients with obstructive sleep apnea. Am Rev Respir Dis 1984; 130: 175-178.

21. Koenig JE, Thach BT. Effects of mass loading on the upper airway. J Appl Physiol 1988; 64: 2294-2299.

22. Koopmann CF, Field RA, Coulthard SW. Sleep apnea syndrome associated with a neck mass. Otolaryngol Head Neck Surg 1981; 89: 949-952.

23. Davies RJO, Stradling JR. The relationship between neck circumference, radiographic pharyngeal anatomy, and the obstructive sleep apnoea syndrome. Eur Respir $J$ 1990; 3: 509-514.

24. Stradling JR, Crosby JH. Predictors and prevalence of obstructive sleep apnoea and snoring in 1,001 middleaged men. Thorax 1991; 46: 85-90.

25. Strohl KP, Saunders NA, Feldman NT, Hallett M. Obstructive sleep apnea in family members. $N$ Engl $J$ Med 1978; 229: 969-973.

26. Manon-Espaillat R, Gothe B, Adams N, Newman C, Ruff R. Familial "sleep apnea plus" syndrome: report of a family. Neurology 1988; 38: 190-193.

27. El Bayadi S, Millman RP, Tishler PV, et al. A family study of sleep apnea: anatomic and physiologic interactions. Chest 1990; 98: 554-559.

28. Redline S, Tosteson T, Tishler PV, Carskadon MA, Milliman RP. Studies in the genetics of obstructive sleep apnea: family aggregation of symptoms associated with sleep-related breathing disturbances. Am Rev Respir Dis 1992; 145: 440-444.

29. Douglas NJ, Luke M, Mathur R. Is the sleep apnoea/ hypopnoea syndrome inherited? Thorax 1993; 48: 719721.

30. Scrima L, Broudy M, Nay KN, Cohn MA. Increased severity of obstructive sleep apnea after bedtime alcohol ingestion. Sleep 1982; 5: 318-328.

31. Issa FG, Sullivan CE. Alcohol, snoring, and sleep apnea. J Neurol Neurosurg Psychiat 1982; 5: 353-359.

32. Guilleminault C, Rosekind M. The arousal threshold: 
sleep deprivation, sleep fragmentation, and obstructive sleep apnea syndrome. Bull Eur Physiopathol Respir 1981; 17: 341-349.

33. Krol RC, Knuth SL, Bartlett D. Selective reduction of genioglossal muscle activity by alcohol in normal subjects. Am Rev Respir Dis 1984; 129: 247-250.

34. Bonora M, Shields GI, Knuth SL, Bartlett D Jr, St John WM. Selective depression by ethanol of upper airway respiratory motor activity in cats. Am Rev Respir Dis 1984; 130: 156-161.

35. Bonora M, St. John WM, Bledsoe TA. Differential elevation by protriptyline and depression by diazepam of upper airway respiratory motor activity. Am Rev Respir Dis 1985; 131: 41-45.

36. Hershensen M, Brouillette RT, Olsen E, Hunt CE. The effect of chloral hydrate on genioglossal and diaphragm activity. Pediatr Res 1984; 18: 516-519.

37. Hwang J, St. John WM, Bartlett D Jr. Respiratoryrelated hypoglossal nerve activity: influence of anesthetics. J Appl Physiol: Respirat Environ Exercise Physiol 1983; 55: 785-792.

38. Lopes JM, Tabachnik E, Muller NL, Levison H, Bryan AC. Total airway resistance and respiratory muscle activity during sleep. J Appl Physiol: Respirat Environ Exercise Physiol 1983; 54: 733-737.

39. Orr WC, Martin RJ. Obstructive sleep apnea associated with tonsillar hypertrophy in adults. Arch Intern Med 1981; 141: 990-992.

40. Sussman D, Podoshin L, Alroy G. The Pickwickian syndrome with hypertrophy of tonsils: a reappraisal. Laryngoscope 1975; 85: 565-569.

41. Stradling JR, Thomas G, Warley ARH, Williams P, Freeland A. Effect of adenotonsillectomy on nocturnal hypoxaemia, sleep disturbance, and symptoms in snoring children. Lancet 1990, 335: 249-253.

42. Schafer ME. Upper airway obstruction and sleep disorders in children with craniofacial anomalies. Clin Plast Surg 1982; 9: 555-567.

43. Conway WA, Bower GC, Barnes ME. Hypersomnolence and intermittent upper airway obstruction: occurrence caused by micrognathia. J Am Med Assoc 1977; 237: 2740-2742.

44. Lauritzen C, Lilja J, Jarlstedt J. Airway obstruction and sleep apnea in children with craniofacial anomalies. Plast Reconstr Surg 1986; 77: 1-5.

45. Sher AE. Mechanisms of airway obstruction in Robin Sequence: Implications for treatment. Cleft Palate Craniofac J 1992; 29: 224-231.

46. Guilleminault C. Surgical treatment of obstructive sleep apnoea. In: Kryger MH, Roth T, Dement WC. eds. Principles and Practice of Sleep Medicine. Philadelphia W.B. Saunders Co., 1989: pp. 571-583.

47. Orr WC, Males JL, Imes NK. Myxedema and obstructive sleep apnea. Am J Med 1981; 70: 1061-1066.

48. Perks WH, Horrocks P, Cooper RA, et al. Sleep apnea in acromegaly. Am Rev Respir Dis 1980; 121: A175.

49. Grunstein RR, Kian YH, Sullivan CE. Sleep apnea in acromegaly. Ann Intern Med 1991; 115: 527-532.

50. Zorick F, Roth T, Kramer M, Flessa H. Exacerbation of upper-airway sleep apnea by lymphatic lymphoma. Chest 1980; 77: 689-690.

51. Perks WH, Cooper RA, Bradbury S, et al. Sleep apnea in Scheie's syndrome. Thorax 1980; 35: 85-91.

52. Safar P, Escarraga LA, Chang F. Upper airway obstruction in the unconscious patient. J Appl Physiol 1959; 14: 760-764.

53. Spann RW, Hyatt RE. Factors affecting upper airway resistance in conscious man. J Appl Physiol 1971; 31: 708-712.

54. Wilson SL, Thach BT, Brouillette RT, Abu-Osba YK. Upper airway patency in the human infant: influence of airway pressure and posture. J Appl Physiol: Respirat Environ Exercise Physiol 1980; 48: 500-504.

55. Morikawa S, Safar P, DeCarlo J. Influence of the headjaw position upon upper airway patency. Anesthesia 1981; 22: 265-270.

56. Gleeson K, Zwillich CW, Brair K, White DP. Breathing route during sleep. Am Rev Respir Dis 1986; 134: 115-120.

57. Proctor DF. The upper airways. I. Nasal physiology and defense of the lungs. Am Rev Respir Dis 1977; 115: 97-129.

58. Rundcrantz H. Postural variations in nasal resistance. Acta Otolaryngol (Stockh) 1969; 68: 435-443.

59. Cole P, Haight JS. Posture and nasal patency. Am Rev Respir Dis 1984; 129: 351-354.

60. Martin RJ, Pennock BE, Orr WC, Sanders MH, Rogers RM. Respiratory mechanics and timing during sleep in occlusive sleep apnea. J Appl Physiol 1980; 48: 432-437.

61. Anch AM, Remmers JE, Bunce H. Supraglottic airway resistance in normal subjects and patients with occlusive sleep apnea. J Appl Physiol: Respirat Environ Exercise Physiol 1982; 53: 1158-1163.

62. Irvine BWH, Dayal VS, Phillipson EA. Sleep apnea due to nasal valve obstruction. J Otolaryngol 1984; 13: 37-38.

63. Zwillich CW, Pickett C, Hanson FN, Weil JV. Disturbed sleep and prolonged apnea during nasal obstruction in normal men. Am Rev Respir Dis 1981; 124: 158-160.

64. Olsen KD, Kern EB, Westbrook PR. Sleep and breathing disturbance secondary to nasal obstruction. Otolaryngol Head Neck Surg 1981; 89: 804-810.

65. Suratt PM, Turner BL, Wilhoit SC. Effect of intranasal obstruction on breathing during sleep. Chest 1986; 90 324-329.

66. McNicholas WT, Tarlo S, Cole P, et al. Obstructive apneas during sleep in patients with seasonal allergic rhinitis. Am Rev Respir Dis 1982; 126: 625-628.

67. Lavie P, Zomer J, Eliaschar F, et al. Excessive daytime sleepiness and insomnia associated with deviated nasal septum and nocturnal breathing disorders. Arch Otolaryngol 1982; 108: 373-377.

68. Wetmore SJ, Scrima L, Hiller FC. Sleep apnea in epistaxis patients treated with nasal packs. Otolaryngol Head Neck Surg 1988; 98: 596-599.

69. McNicholas WT, Coffey M, McDonnell T, O'Regan R, Fitzgerald MX. Upper airway obstruction during sleep in normal subjects after selective topical oropharyngeal anesthesia. Am Rev Respir Dis 1987; 135: 1316-1319.

70. White DP, Cadieux RJ, Lombard RM, Bixler EO, Kales A, Zwillich CW. The effects of nasal anesthesia on breathing during sleep. Am Rev Respir Dis 1985; 132; 972-975.

71. McNicholas WT, Coffey M, Boyle T. Effects of nasal airflow on breathing during sleep in normal humans. $A m$ Rev Respir Dis 1993; 147: 620-623.

72. Riley R, Guilleminault C, Herran J, Powell N. Cephalometric analyses and flow volume loops in obstructive sleep apnoea patients. Sleep 1983; 6: 303-311.

73. Rivlin J, Hoffstein V, Kalbfleisch J, McNicholas W, Zamel N, Bryan AC. Upper airway morphology in patients with idiopathic obstructive sleep apnea. Am Rev Respir Dis 1984; 129: 355-360.

74. Fredburg JJ, Wohl MB, Glass GM, Dorkin HL. Airway 
area by acoustic reflections measured at the mouth. $J$ Appl Physiol: Respirat Environ Exercise Physiol 1980; 48: 749-758.

75. Brown IB, McClean PA, Boucher R, Zamel N, Hoffstein V. Changes in pharyngeal cross-sectional area with posture and application of continuous positive airway pressure in patients with obstructive sleep apnea. Am Rev Respir Dis 1987; 136: 628-632.

76. Shepard JW Jr, Thawley SE. Evaluation of the upper airway by computerised tomography in patients undergoing uvulopalatopharyngoplasty for obstructive sleep apnea. Am Rev Respir Dis 1989; 140: 711-716.

77. Stauffer JL, Zwillich CW, Cadieux RJ, et al. Pharyngeal size and resistance in obstructive sleep apnea. Am Rev Respir Dis 1987; 136: 623-627.

78. Larsson S-G, Gislason T, Lindholm CE. Computed tomography of the oropharynx in obstructive sleep apnea. Acta Radiologica 1988; 9: 401-405.

79. Abbey NC, Block AJ, Green D, Mancuso A, Hellard DW. Measurement of pharyngeal volume by digitized magnetic resonance imaging. Effect of nasal continuous positive airway pressure. Am Rev Respir Dis 1989; 140: 717-723.

80. Rodenstein DO, Dooms G, Thomas Y, et al. Pharyngeal shape and dimensions in healthy subjects, snorers, and patients with obstructive sleep apnoea. Thorax 1990; 45: 722-727.

81. Haponik EF, Blecker ER, Allen RP, Smith PL, Kaplan J. Abnormal inspiratory flow-volume curves in patients with sleep-disordered breathing. Am Rev Respir Dis 1981; 24: 571-579.

82. Sanders MH, Martin RJ, Pennock BE, Rogers RM. The detection of sleep apnea in the awake patient. $\mathrm{J} \mathrm{Am} \mathrm{Med}$ Assoc 1981; 245: 2414-2418.

83. Schwab RJ, Gefter WB, Hoffman EA, Gupta KB, Pack AI. Dynamic upper airway imaging during awake respiration in normal subjects and patients with sleep disordered breathing. Am Rev Respir Dis 1993; 148: 13851400 .

84. Guilleminault C, Hill MW, Simmons FB, Dement WC. Obstructive sleep apnea: electromyographic and fiberoptic studies. Exp Neurol 1978; 62: 48-67.

85. Fouke JM, Strohl KP. Effect of position and lung volume on upper airway geometry. J Appl Physiol 1987; 63: 375-380.

86. Yildirim N, Fitzpatrick MF, Whyte KF, Jalleh R, Wightman AJA, Douglas NJ. The effect of posture on upper air-way dimensions in normal subjects and in patients with the sleep apnea/hypopnea syndrome. Am Rev Respir Dis 1991; 144: 845-847.

87. Jan MA, Marshall I, Douglas NJ. Effect of posture on upper airway dimensions in normal human. Am $J$ Respir Crit Care Med 1994; 149: 145-148.

88. Douglas NJ, Jan MA, Yildirim N, Warren PM, Drummond GB. Effect of posture and breathing route on genioglossal electromyogram activity in normal subjects and in patients with the sleep apnea/hypopnea syndrome. Am Rev Respir Dis 1993; 148: 1341-1345.

89. Hudgel DW, Martin J, Johnson B, Hill P. Mechanics of the respiratory system and breathing pattern during sleep in normal humans. J Appl Physiol: Respirat Environ Exercise Physiol 1984; 56: 133-137.

90. Tabachnik E, Muller NL, Bryan AC, Levison H. Changes in ventilation and chest wall mechanics during sleep in normal adolescents. J Appl Physiol: Respirat Environ Exercise Physiol 1981; 51: 557-564.

91. Wiegand L, Zwillich CW, White DP. Collapsibility of the human upper airway during normal sleep. $J$ Appl Physiol 1989; 66: 1800-1808.

92. Wiegand DA, Latz B, Zwillich CW, Wiegand L. Upper airway resistance and geniohyoid muscle activity in normal men during wakefulness and sleep. J Appl Physiol 1990; 69: 1252-1261.

93. DeWeese EL, Sullivan TY. Effects of upper airway anesthesia on pharyngeal patency during sleep. J Appl Physiol 1988; 64: 1346-1353.

94. Hudgel DW, Hendricks C. Palate and hypopharynx: sites of inspiratory narrowing of the upper airway during sleep. Am Rev Respir Dis 1988; 138: 1542-1547.

95. Skatrud JB, Dempsey JA. Airway resistance and respiratory muscle function in snorers during NREM sleep. $J$ Appl Physiol 1985; 59: 328-335.

96. Suratt PM, McTier RF, Wilhoit SC. Collapsibility of the nasopharyngeal airway in obstructive sleep apnea. Am Rev Respir Dis 1985; 132: 967-971.

97. Sanders MH, Moore SE. Inspiratory and expiratory partitioning of airway resistance during sleep in patients with sleep apnea. Am Rev Respir Dis 1983; 127: 554-558.

98. Sanders MH, Rogers RM, Pennock BE. Prolonged expiratory phase in sleep apnea: a unifying hypothesis. Am Rev Respir Dis 1985; 131: 401-408.

99. Hudgel DW. Variable site of airway narrowing among obstructive sleep apnea patients. J Appl Physiol 1986; 61: 1403-1409.

100. Brown G, Bradley TD, Phillipson EA, Zamel N, Hoffstein V. Pharyngeal compliance in snoring subjects with and without obstructive sleep apnea. Am Rev Respir Dis 1985; 132: 211-215.

101. Suratt PM, Wilhoit SC, Cooper K. Induction of airway collapse with subatmospheric pressure in awake patients with obstructive sleep apnea. J Appl Physiol: Respirat Environ Exercise Physiol 1984; 57: 140-146.

102. Smith PL, Wise RA, Gold AR, Schwartz AR, Permutt S. Upper airway pressure-flow relationships in obstructive sleep apnea. J Appl Physiol 1988; 64: 789-795.

103. Schwartz AR, Smith PL, Wise RA, Gold AR, Permutt $\mathrm{S}$. Induction of upper airway occlusion in sleeping individuals with subatmospheric nasal pressure. $J$ Appl Physiol 1988; 64: 535-542.

104. Block AJ, Faulkner JA, Hughes RL, Remmers JE, Thach B. Factors influencing upper airway closure. Chest 1984; 86: 114-122.

105. Strohl KP. Upper airway muscles of respiration. $A m$ Rev Respir Dis 1981; 124: 211-213.

106. Brouillette RT, Thach BT. A neuromuscular mechanism maintaining extrathoracic airway patency. $J$ Appl Physiol: Respirat Environ Exercise Physiol 1979; 46: 772-779.

107. Brouillette RT, Thach BT. Control of genioglossus muscle inspiratory activity. J Appl Physiol: Respirat Environ Exercise Physiol 1980; 49: 801-808.

108. Weiner D, Mitra J, Salamone J, Cherniack NS. Effect of chemical stimuli on nerves supplying upper airway muscles. J Appl Physiol: Respirat Environ Exercise Physiol 1982; 52: 530-536.

109. Önal E, Lopata M, O'Connor TD. Diaphragmatic and genioglossal electromyogram responses to isocapnic hypoxia in humans. Am Rev Respir Dis 1981; 124: 215-217.

110. Önal E, Lopata M, O'Connor TD. Diaphragmatic and genioglossal electromyogram responses to $\mathrm{CO}_{2}$ rebreathing in humans. J Appl Physiol: Respirat Environ Exercise Physiol 1981; 50: 1052-1055.

111. Horner RL, Innes JA, Murphy K, Guz A. Evidence for reflex upper airway dilator muscle activation by sudden 
negative pressure in man. J Physiol (Lond) 1991; 436: $15-29$.

112. Horner RL, Innes JA, Holden HB, Guz A. Afferent pathway(s) for pharyngeal dilator reflex to negative pressure in man: a study using upper airway anaesthesia. $J$ Physiol (Lond) 1991; 436: 31-44.

113. Issa FG, Sullivan CE. Arousal and breathing responses to airway occlusion in healthy sleeping adults. $J$ Appl Physiol: Respirat Environ Exercise Physiol 1983; 55: 1113-1119.

114. Önal E, Lopata M. Periodic breathing and the pathogenesis of occlusive sleep apneas. Am Rev Respir Dis 1982; 126: 676-680.

115. Strohl KP, Hensley MJ, Hallett M, Saunders NA, Ingram RH. Activation of upper airway muscles before onset of inspiration in normal humans. J Appl Physiol: Respirat Environ Exercise Physiol 1980; 49: 638-642.

116. Suratt PM, McTier R, Wilhoit SC. Alae nasi electromyographic activity and timing in obstructive sleep apnea. J Appl Physiol 1985; 58: 1252-1256.

117. Sauerland EK, Harper RM. The human tongue during sleep: electromyographic activity of the genioglossus muscle. Exp Neurol 1976; 51: 160-170.

118. Issa FG, Edwards P, Szeto E, Lauff D, Sullivan C. Genioglossus and breathing responses to airway occlusion: effect of sleep and route of occlusion. J Appl Physiol 1988; 64: 543-549.

119. Önal E, Lopata M, O'Connor T. Pathogenesis of apneas in hypersomnia-sleep apnea syndrome. Am Rev Respir Dis 1982; 125: 167-174.

120. Parisi RA, Neubauer JA, Frank MM, Edelman NH, Santiago TV. Correlation between genioglossal and diaphragmatic responses to hypercapnia during sleep. $\mathrm{Am}$ Rev Respir Dis 1987; 135; 378-382.

121. Suratt PM, McTier RF, Wilhoit SC. Upper airway muscle activation is augmented in patients with obstructive sleep apnea compared with that in normal subjects. Am Rev Respir Dis 1988; 137: 889-894.

122. Van de Graaff WB, Gottfried SB, Mitra J, Van Lunteren E, Cherniack NS, Strohl KP. Respiratory function of hyoid muscles and hyoid arch. J Appl Physiol: Respirat Environ Exercise Physiol 1984; 57: 197-204.

123. Van Lunteren E, Haxhiu MA, Cherniack NS. Mechanical function of hyoid muscles during spontaneous breathing in cats. J Appl Physiol 1987; 62: 582-590.

124. Van Lunteren E, Haxhiu MA, Cherniack NS. Relationship between upper airway volume and hyoid muscle length. J Appl Physiol 1987; 63: 1443-1449.

125. Wiegand DA, Latz B, Zwillich CW, Wiegand L. Geniohyoid muscle activity in normal men during wakefulness and sleep. J Appl Physiol 1990; 69: 1262-1269.

126. Roberts JL, Reed WR, Thach BT. Pharyngeal airwaystabilizing function of hyoid muscles and the hyoid arch. J Appl Physiol: Respirat Environ Exercise Physiol 1984; 57: 1790-1795.

127. Sauerland EK, Orr WC. Hainston LE. EMG patterns of oropharyngeal muscles during respiration in wakefulness and sleep. Electromyogr Clin Neurophysiol 1981; 21: 307-316.

128. Tangel DJ, Mezzanotte WS, White DP. Influence of sleep on tensor palatini EMG and upper airway resistance in normal men. J Appl Physiol 1991; 70: 2574-2581.

129. Anch AM, Remmers JE, Sauerland EK, DeGroot WJ. Oropharyngeal patency during waking and sleep in the Pickwickian syndrome: electromyographic activity of the tensor veli palatini. Electromyogr Clin Neurophysiol 1981; 21: 317-330.
130. Hairston LE, Sauerland EK. Electromyography of the human palate: Discharge patterns of the levator and tensor veli palatini. Electromyogr Clin Neurophysiol 1981; 21: 287-297.

131. Tangel DJ, Mezzanotte WS, Sandberg EJ, White DP. Influences of NREM sleep on the activity of tonic $v s$ inspiratory phasic muscles in normal men. J Appl Physiol 1992; 73: 1058-1066.

132. Strohl KP, Olson LG. Concerning the importance of pharyngeal muscles in the maintenance of upper airway patency during sleep: an opinion. Chest 1987; 92: 918-920.

133. Patrick GB, Strohl KP, Rubin SB, Altose MD. Upper airway and diaphragm muscle responses to chemical stimulation and loading. J Appl Physiol: Respirat Environ Exercise Physiol 1982; 53: 1133-1137.

134. Van Lunteren E, Strohl KP, Parker DM, Biuce EN, Van de Graff WB, Cherniack NS. Phasic volume-related feedback on upper airway muscle activity. J Appl Physiol: Respirat Environ Exercise Physiol 1984; 56: 730-736.

135. Van Lunteren E, Van de Graaf WB, Parker DM, et al. Nasal and laryngeal reflex responses to negative upper airway pressure. J Appl Physiol: Respirat Environ Exercise Physiol 1984; 56: 746-752.

136. Örem J, Netick A, Dement WC. Increased upper airway resistance to breathing during sleep in the cat. Electroencephalogr Clin Neurophysiol 1977; 43: 14-22.

137. Önal E, Leech JA, Lopata M. Dynamics of respiratory drive and pressure during NREM sleep in patients with occlusive apneas. J Appl Physiol 1985; 58: 1971-1974.

138. Hudgel DW, Harasick T. Fluctuation in timing of upper airway and chest wall inspiratory muscle activity in obstructive sleep apnea. J Appl Physiol 1990; 69: 443-450.

139. Longobardo GS, Gothe B, Goldman MD, Cherniack NS. Sleep apnea considered as a control system instability. Respir Physiol 1982; 50: 311-333.

140. Issa FG, Sullivan CE. Upper airway closing pressures in obstructive sleep apnea. J Appl Physiol: Respirat Environ Exercise Physiol 1984; 57: 520-527.

141. Glenn WW, Gee JBL, Cole DR, Farmer WC, Shaw RK, Beckman CB. Combined central alveolar hypoventilation and upper airway obstruction: treatment by tracheostomy and diaphragm pacing. Am J Med 1978; 64: 50-60.

142. Hyland RH, Hutcheon MA, Perl A, et al. Airway occlusion induced by diaphragm pacing for primary alveolar hypoventilation: implications for the pathogenesis of obstructive sleep apnea. Am Rev Respir Dis 1981; 124: $180-185$.

143. Mathew OP, Remmers JE. Respiratory function of the upper airway. In: Saunders NA, Sullivan CE, eds. Sleep and Breathing: Lung Biology in Health and Disease. Vol. 21. New York, Marcel Dekker, 1984; pp. 163-200.

144. Mathew OP, Abu-Osba YK, Thach BT. Influence of upper airway pressure changes on genioglossus muscle respiratory activity. J Appl Physiol: Respirat Environ Exercise Physiol 1982; 52: 438-444.

145. Mathew OP, Abu-Osba YK, Thach BT. Genioglossus muscle responses to upper airway pressure changes: afferent pathways. J Appl Physiol: Respirat Environ Exercise Physiol 1982; 52: 445-450.

146. Hwang JC, St. John WM, Bartlett D. Afferent pathways for hypoglossal and phrenic responses to changes in upper airway pressure. Respir Physiol 1983; 49: 341-355.

147. Mathew OP. Upper airway negative pressure effects on respiratory activity of upper airway muscles. J Appl Physiol: Respirat Environ Exercise Physiol 1984; 56: 500505. 
148. Sant'Ambrogio G, Mathew OP, Fisher JT, Sant'Ambrogio FB. Laryngeal receptors responding to transmural pressure, airflow and local muscular activity. Respir Physiol 1983; 54: 317-330.

149. Okabe S, Chonan T, Hida W, Satoh M, Kikuchi Y, Takishima T. Role of chemical drive in recruiting upper airway and inspiratory intercostal muscles in patients with obstructive sleep apnea. Am Rev Respir Dis 1993; 147: 190-195.

150. Abu-Osba YK, Mathew OP, Thach BT. An animal model for sensory deprivation producing obstructive apnea with postmortem findings of sudden infant death syndrome. Pediatrics 1981; 68: 796-801.

151. Chadwick GA, Crowley P, Fitzgerald MX, O'Regan RG, McNicholas WT. Obstructive sleep apnoea following topical oropharyngeal anesthesia in loud snorers. Am Rev Respir Dis 1991; 143; 810-813.

152. Deegan PC, McNicholas WT. Effects of topical anesthesia (TOPA) during sleep in patients with clinically significant obstructive sleep apnea (OSA). Am Rev Respir Dis 1993; 147: A764.

153. Larsson H, Carlsson-Nordlander B, Lindblad LE, Norbeck $\mathrm{O}$, Svanborg E. Temperature thresholds in the oropharynx of patients with obstructive sleep apnea syndrome. Am Rev Respir Dis 1992; 146: 1246-1249.

154. Wheatley JR, Mezanotte WS, Tangel DJ, White DP. Influence of sleep on genioglossus muscle activation by negative pressure in normal men. Am Rev Respir Dis 1993; 148: 597-605.

155. Aronson RM, Onal E, Carley DW, Lopata M. Upper airway and respiratory muscle responses to continuous negative airway pressure. J Appl Physiol 1989; 66: 1373-1382.

156. Sullivan CE, Issa FG, Berthon-Jones M, Eves L. Reversal of obstructive sleep apnoea by continuous positive airway pressure applied through the nares. Lancet 1981; i: $862-865$.

157. Strohl KP, Redline S. Nasal CPAP therapy, upper airway muscle activation, and obstructive sleep apnea. Am Rev Respir Dis 1986; 134: 555-558.

158. Deegan PC, Nolan P, O'Regan RG, McNicholas WT. Effects of continuous and expiratory positive airway pressure on alae nasi and genioglossus muscle activity in awake normal humans. Am Rev Respir Dis 1993; 147: A767.

159. Deegan PC, Nolan P, McNicholas WT. Effects of continuous and expiratory positive airway pressure on alae nasi and genioglossus muscle activity in sleeping normal humans. Am J Respir Crit Care Med 1994; 149: A145.

160. Mahadevia AK, Önal E, Lopata M. Effects of expiratory positive airway pressure on sleep-induced respiratory abnormalities in patients with hypersomnia-sleep apnea syndrome. Am Rev Respir Dis 1983; 1128: 708-711.

161. Cherniack NS. Respiratory dysrhythmias during sleep. $N$ Engl J Med 1981; 305: 325-330.

162. Rubenstein I, Hoffstein V, Bradley TD. Lung volumerelated changes in the pharyngeal area of obese females with and without obstructive sleep apnoea. Eur Respir $J$ 1989; 2: 344-351.

163. McNicholas WT, Bowes G, Zamel N, Phillipson EA. Impaired detection of added inspiratory resistance in patients with obstructive sleep apnea. Am Rev Respir Dis 1984; 129: 45-48.

164. Berssenbrugge A, Dempsey J, Iber C, Skatrud J, Wilson P. Mechanisms of hypoxia-induced periodic breathing during sleep in humans. J Physiol 1983; 343: 507-526.

165. Bülow K. Respiration and wakefulness in man. Acta Physiol Scand 1963; 209: (Suppl.) 1-110.
166. Douglas NJ, White DP, Pickett CK, Weil JV, Zwillich CW. Respiration during sleep in normal man. Thorax 1982; 37: 840-844.

167. Berthon-Jones M, Sullivan CE. Ventilatory and arousal responses to hypoxia in sleeping humans. Am Rev Respir Dis 1982; 125: 632-639.

168. Douglas NJ, White DP, Weil JV, et al. Hypoxic ventilatory response decreases during sleep in normal men. Am Rev Respir Dis 1982; 125: 286-289.

169. Douglas NJ, White DP, Weil JV, Pickett CK, Zwillich CW. Hypercapnic ventilatory response in sleeping adults. Am Rev Respir Dis 1982; 125: 758-762.

170. Berthon-Jones M, Sullivan CE. Ventilation and arousal responses to hypercapnia in normal sleeping humans. $J$ Appl Physiol: Respirat Environ Exercise Physiol 1984; 54: 59-67.

171. White DP. Occlusion pressure and ventilation during sleep in normal humans. J Appl Physiol 1986; 61: 1279-1287.

172. Whitelaw WA, Derenne J-P, Milic-Emili J. Occlusion pressure as a measure of respiratory center output in conscious man. Respir Physiol 1975; 23: 181-199.

173. Sériès F, Cormier Y, Desmeules M, La Forge J. Effects of respiratory drive on upper airways in sleep apnea patients and normal subjects. J Appl Physiol 1989; 67: 973-979.

174. Kryger M, Quesney LF, Holder D, Gloor P, Macleod P. The sleep deprivation syndrome of the obese patient. Am J Med 1974; 56; 531-539.

175. Gold AR, Schwartz AR, Wise RA, Smith PL. Pulmonary function and respiratory chemosensitivity in moderately obese patients with sleep apnea. Chest 1993; 103: $1325-1329$

176. Garay SM, Rapoport D, Sorkin B, Epstein H, Feinberg I, Goldring RM. Regulation of ventilation in the obstructive sleep apnea syndrome. Am Rev Respir Dis 1981; 124: 451-457.

177. Lopata M, Önal E. Mass loading, sleep apnea, and the pathogenesis of obesity hypoventilation. Am Rev Respir Dis 1982; 126: 640-645.

178. Berthon-Jones M, Sullivan CE. Time course of change in ventilatory response to $\mathrm{CO}_{2}$ with long-term CPAP therapy for obstructive sleep apnea. Am Rev Respir Dis 1987; 135: 144-147.

179. Hudgel DW, Hendricks C, Dadley A. Alteration in obstructive apnoea pattern induced by changes in oxygen and carbon dioxide inspired concentrations. Am Rev Respir Dis 1988; 138: 16-19.

180. Greenberg HE, Scharf S. Depressed ventilatory load compensation in sleep apnea: reversal by nasal CPAP. Am Rev Respir Dis 1993; 148: 1610-1615.

181. Iber C, Bessenbrugge A, Skatrud JB, Dempsey JA. Ventilatory adaptations to resistive loading during wakefulness and non-REM sleep. J Appl Physiol: Respirat Environ Exercise Physiol 1982; 52: 607-614.

182. Santiago TV, Sinha AK, Edelman NH. Respiratory flow-resistive load compensation during sleep. Am Rev Respir Dis 1981; 123: 382-387.

183. Wiegand L, Zwillich CW, White DP. Sleep and the ventilatory response to resistive loading in normal man. $J$ Appl Physiol 1988; 63: 1186-1195.

184. Wilson PA, Skatrud JB, Dempsey JA. Effects of slow wave sleep on ventilatory compensation to inspiratory elastic loading. Respir Physiol 1984; 55: 103-120.

185. Guilleminault C. Sleep apnea syndromes: impact of sleep and sleep states. Sleep 1980; 3: 227-234.

186. Vincken W, Guilleminault C, Silvestri L, Cosio M, 
Grassino A. Inspiratory muscle activity as a trigger causing the airways to open in obstructive sleep apnea. Am Rev Respir Dis 1987; 135: 372-377.

187. Kimoff RJ, Cheong TH, Olha AE, et al. Mechanisms of apnea termination in obstructive sleep apnea: role of chemoreceptor and mechanoreceptor stimuli. Am J Respir Crit Care Med 1994; 149: 707-714.

188. Berry RB, Prosise GL, Light RW. Effect of upper airway anesthesia on apnea duration and arousal. Am Rev Respir Dis 1993; 147: A513.

189. Godfrey S, Campbell EJM. The control of breathholding. Respir Physiol 1968; 5: 385-400.

190. Whitelaw WA. McBride B, Amar J, Corbet K. Respiratory neuromuscular output during breathholding. J Appl Physiol: Respirat Environ Exercise Physiol 1981; 50: 435-443.

191. Martin RJ, Sanders M, Gray BA, Pennock BE. Acute and long-term effects of hyperoxia in the adult sleep apnea syndrome. Am Rev Respir Dis 1982; 125: 175-180.

192. Gold AR, Schwartz AR, Bleecker ER, Smith PL. The effect of chronic nocturnal oxygen administration upon sleep apnea. Am Rev Respir Dis 1986; 134: 925-929.

193. Alford NJ, Fletcher EC, Nickeson D. Acute oxygen in patients with sleep apnea and COPD. Chest 1986; 89: 30-38.

194. Smith PL, Haponik EF, Bleecker ER. The effects of oxygen in patients with sleep apnea. Am Rev Respir Dis 1984; 130: 958-963.

195. Phillips BA, Schmitt FA, Berry DTR, Lamb DG, Amin M, Cook YR. Treatment of obstructive sleep apnea: a preliminary report comparing nasal CPAP to nasal oxygen in patients with mild OSA. Chest 1990; 98: 325330.

196. Phillipson EA, Sullivan CE. Arousal: the forgotten response to respiratory stimuli. Am Rev Respir Dis 1978; 118: 807-809.

197. Nolan P, O'Donnell J, Deegan PC, O'Regan R, McNicholas WT. Role of cortical arousal in the ventilatory response to airway occlusion during sleep. Am Rev Respir Dis 1993; 147: A514.

198. Issa FG, McNamara SG, Sullivan CE. Arousal responses to airway occlusion in sleeping dogs: comparison of nasal and tracheal occlusions. J Appl Physiol 1987; 62: 1832-1836.

199. Basner RC, Ringler J, Garpestad E, et al. Upper airway anesthesia delays arousal from airway occlusion induced during human NREM sleep. J Appl Physiol 1992; 73: 642-648.

200. Sullivan CE, Kozar LF, Murphy E, Phillipson EA. Arousal, ventilatory, and arousal responses to bronchopulmonary stimulation in sleeping dogs. J Appl Physiol: Respirat Environ Exercise Physiol 1979; 47: 17-25.

201. Sullivan CE, Murphy E, Kozar LF, Phillipson EA. Waking and ventilatory responses to laryngeal stimulation in sleeping dogs. J Appl Physiol: Respirat Environ Exercise Physiol 1978; 45: 681-689.

202. Gleeson K, Zwillich CW, White DP. The influence of increasing ventilatory effort on a from sleep. Am Rev Respir Dis 1990; 142: 295-300.

203. Bowes G, Townsend ER, Bromley SM, Kozar LF, Phillipson EA. Role of carotid body and of afferent vagal stimuli in the arousal response to airway occlusion in sleeping dogs. Am Rev Respir Dis 1981; 123: 644-647.

204. Bowes G, Townsend ER, Kozar LF, Bromley SM, Phillipson EA. Effect of carotid body denervation on arousal response in sleeping dogs. J Appl Physiol: Respirat Environ Exercise Physiol 1981; 51: 40-45.

205. Fleetham J, West P, Mezon B, Conway W, Roth T, Kryger M. Sleep, arousals, and oxygen desaturation in chronic obstructive pulmonary disease: the effect of oxygen therapy. Am Rev Respir Dis 1982; 126: 429-433.

206. Guilleminault C, Stoohs R, Clerk A, Cetel M, Maistros P. A cause of excessive daytime sleepiness: the upper airway resistance syndrome. Chest 1993; 104: 781-787.

207. Hedemark LL, Kronenberg RS. Ventilatory and heart rate responses to hypoxia and hypercapnia during sleep in adults. J Appl Physiol: Respirat Environ Exercise Physiol 1982; 53: 307-312.

208. Rechtschaffen A, Kales A. In: A manual of standardised terminology, techniques and scoring system for sleep stages in human subjects. Washington, DC, National Institutes of Health, 1968; publication No. 204.

209. Salinsky M, Goin S, Sutula S, Roscoe D, Weber S. Comparison of sleep staging by polygraph and color density spectral array. Sleep 1988; 11: 131-138.

210. Rees K, Spence DPS, Calverley PMA. Arousal responses from apnoeic events during NREM sleep. Am Rev Respir Dis 1993; 147: A513.

211. Guilleminault C, Cummiskey J. Progressive improvement of apnea index and ventilatory response to $\mathrm{CO}_{2}$ after tracheostomy in obstructive sleep apnea. Am Rev Respir Dis 1982; 126: 14-20.

212. Bradley TD, McNicholas WT, Rutherford R, Popkin J, Zamel N, Phillipson EA. Clinical and physiologic heterogeneity of the central sleep apnea syndrome. Am Rev Respir Dis 1986; 134: 217-221.

213. Krieger J, Kurtz D. Objective measurement of compliance with nasal CPAP treatment for obstructive sleep apnea syndrome. Eur Respir J 1988; 1: 436-438.

214. Reeves-Hoche MK, Meck R, Zwillich CW. Long-term compliance with nasal continuous positive airway pressure therapy (CPAP). Am Rev Respir Dis 1992; 145: A169.

215. Rauscher H, Formanek D, Popp W, Zwick H. Selfreported $v s$ measured compliance with nasal CPAP for obstructive sleep apnea. Chest 1993; 103: 1675-1680. 